\title{
النساسـخ خالمنسـوخ
}

$$
\begin{aligned}
& \text { في تفســـــير } \\
& \text { ( فتح الرحمن في تفسير القرآن) } \\
& \text { للعليمي توYYهـ } \\
& \text { إعداد } \\
& \text { د/ إنصاف حيدر صديق موسي } \\
& \text { أستاذ مساعد سابق بفرع جامعة الطائف }
\end{aligned}
$$




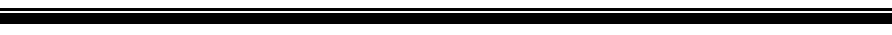

\section{مقدمة البحث}

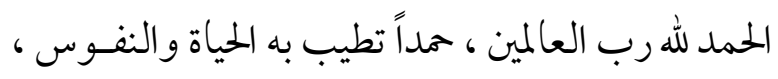

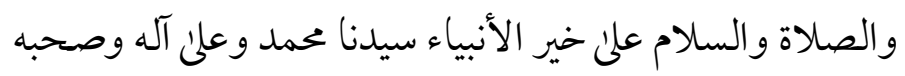

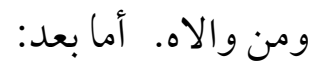

فيطيب لي أن أطرح لكم موضوعًا مهـًا مـن المواضـيع

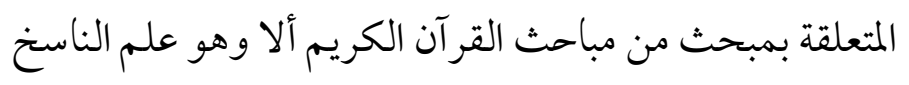

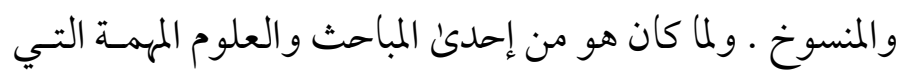

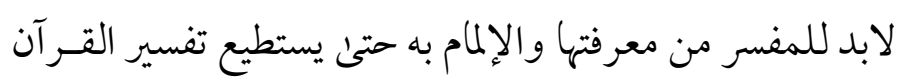

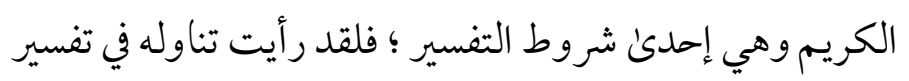

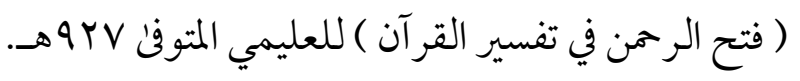

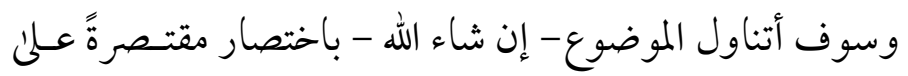
بعض النماذج في تفسيره، كما سوف اقسم البحث إلى مباحث : • المقدمة المبحث الأول: ترجمة للمفسر • المبحث الثاني: تعريف النسخ وأهميته وشروطه...

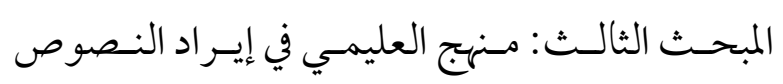
الناسخة والمنسوخة من القرآن الكريم

$$
\text { قائمة المصادر والمر اجع }
$$




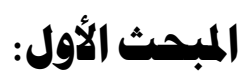

$$
\begin{aligned}
& \text { الإمام القاضي بجير الدين بن محمد العُلَيَمِي المقدسي الحنبلي } \\
& \text { تصPR }
\end{aligned}
$$

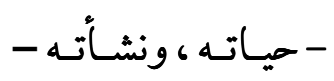

$$
\begin{aligned}
& \text { (سمها: عبد الرحمن بن محمد بن عبد الرحمن بن محمد العليمي (1) } \\
& \text { المقدسي الحنبلي أبو اليمن مجير الدين العمري المنتهي نسبه إلي عبد } \\
& \text { الله بن عمر بن الخطاب- رضي الله عنها - (r). }
\end{aligned}
$$

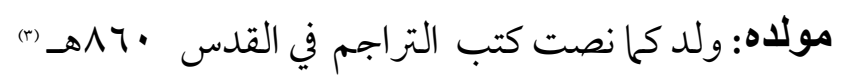

$$
\begin{aligned}
& \text { ا- نشأته ورحلاته الملمية. } \\
& \text { نشأ - رحمه الله - في حجر و الده العلامة قاضى القضاة شمس } \\
& \text { الدين محمد بن عبد الرحمن ، و تفققه عليه ، وأخذ عنـه جملـة مـن } \\
& \text { العلوم النافعة ، وبدت عليه مخايل النجابة منــ الـصغر ، فقـد }
\end{aligned}
$$

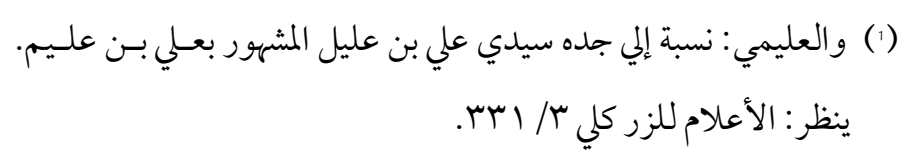

$$
\begin{aligned}
& \text { (2) مختصر طبقات الحنابلة للشطي صــاV و الضوء اللامع لـشمس الـدين }
\end{aligned}
$$

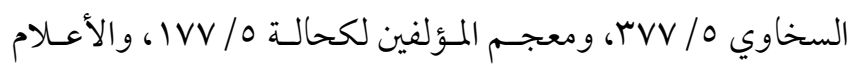

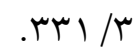

$$
\begin{aligned}
& \text { (3) ينظر : مختصر طبقات الحنابلة للشطي صـrV ، والأعلام r/ آسم. }
\end{aligned}
$$


حفظ " ملحة الإعراب " (1) للحريـري ، وعرضها علي الشيخ محمد بن عبد الله القرمشني، وله ست سنين ، ثـم حفظظ القـرآن وهو في العاشرة من عمره علي الشيخ علاء الدين علي بن عبد الله

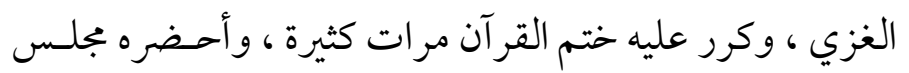

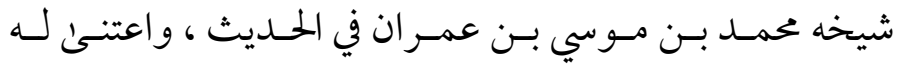

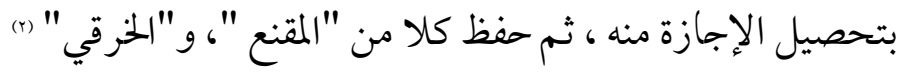

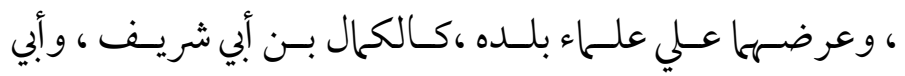

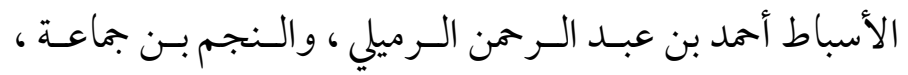

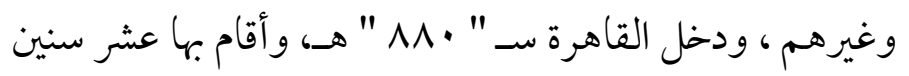
، وحل علي شيخه القاضي بدر الدين السعدي، يقول الشطي: "

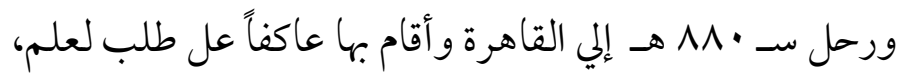
ولزم قاضي الحنابلة بالديار المصرية بدر الدين محمد بـن أبي بكـر

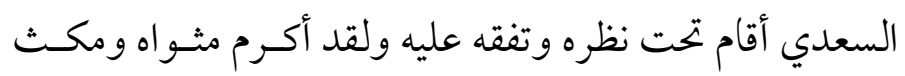
بالديار المصرية نحو عشر سنين وتفقهـ به،وسـمع الحسديث علي جماعة مسنهم : الحافظ السخخاوي،والقطب الخضيري،والجلال

$$
\begin{aligned}
& \text { (1) الشيخ العلامة أبو كمد القاسم بن علي الحريري، تـ } 17 \text { هـــ. }
\end{aligned}
$$

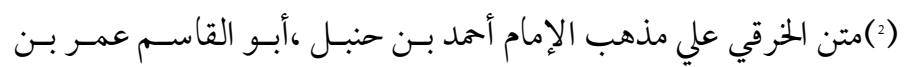

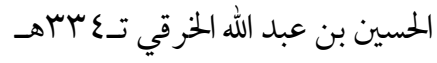


البكري ، وغيرهم، وولي قضاء القدس، وكان من أمثل القضضاة

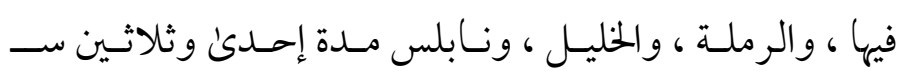

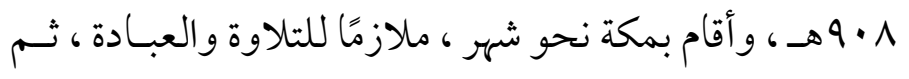

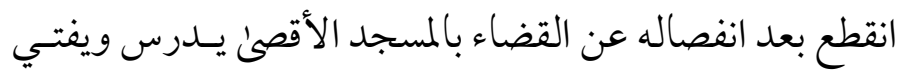

ويؤلف، ولقد كان فطنًا يحب العلم من صغره ذكيّا بجـاًا، وإذا

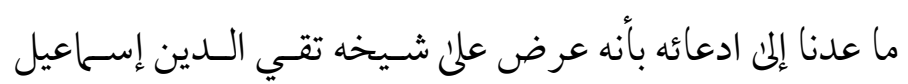

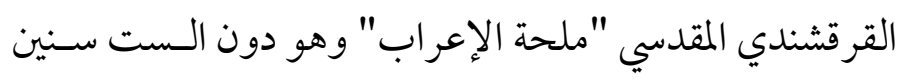
وأجازه الشيخ بالملحة لسنده المتصل إلى المصنف وبغيرهـا مـن فئس

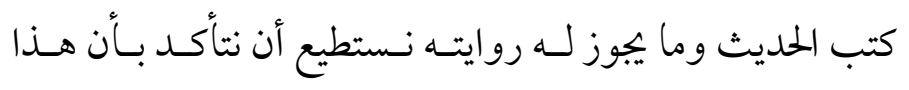

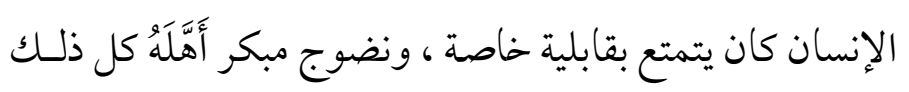

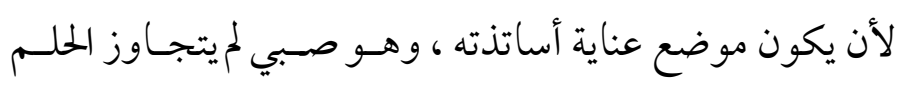

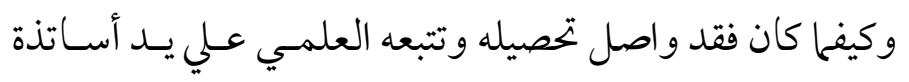
معروفين بالفضل والكهال بحيـث عـرف بالأوساط العلميـة

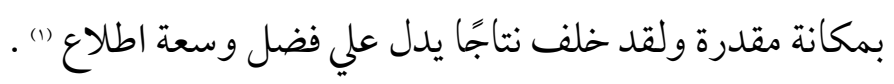

\section{عقيدته.}

لقد سار العليمي - رمه الله تعالم - علي مذهب أهل السنة

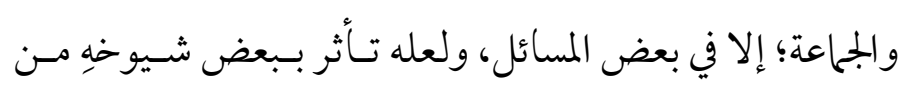

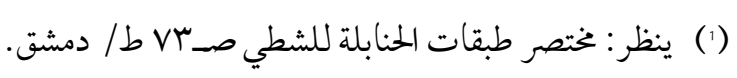




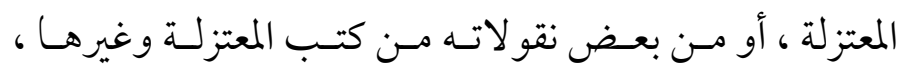

ويتضح ذلك في تفسيره ، وهو يسلك منهج أهل السنة والجماعـة

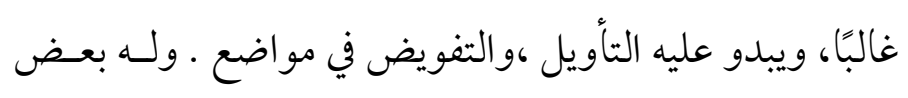

النقول من كتب المعتزلة كتفسير الكشاف ، التي يخـالفون فيها

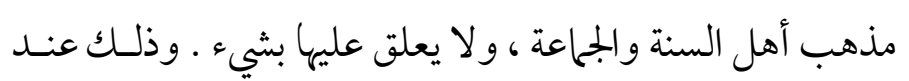

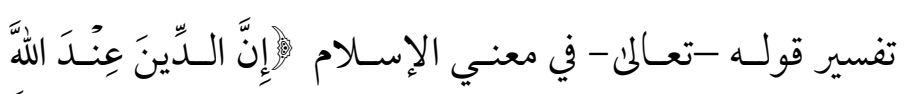

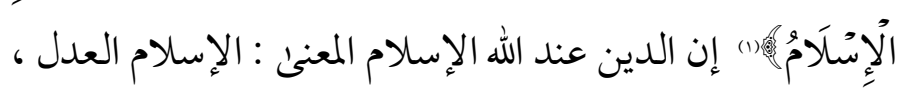

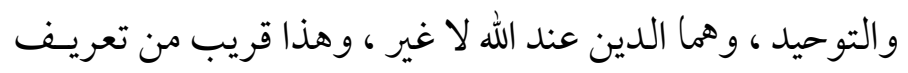

المعتزلة للإسالام ().

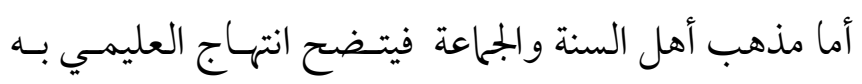

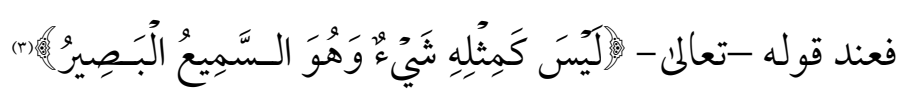

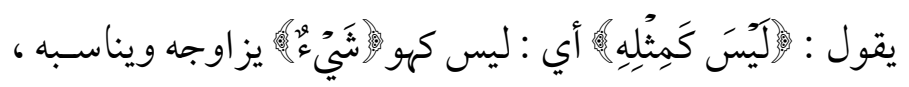

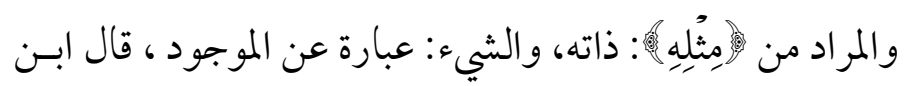

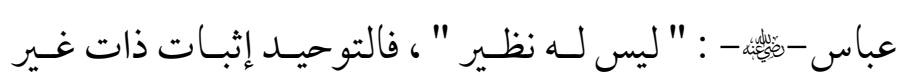

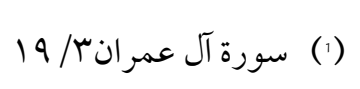

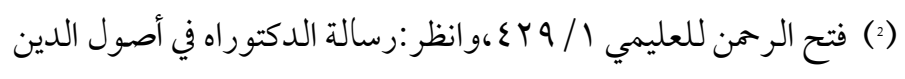

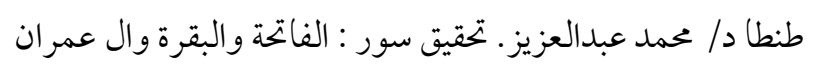

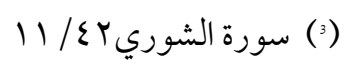


مشبهة للذوات ، و لا معطلة من الصفات ، ليس كذاته ذوات ،

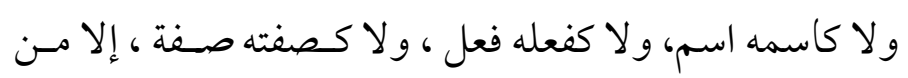

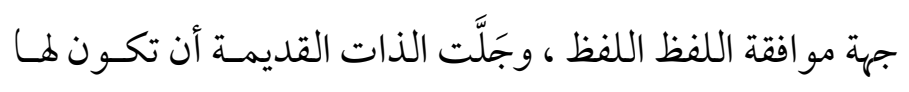
صفة حديثة ، كما استحال أن تكون للذات المحدثة صفة قديمة ،

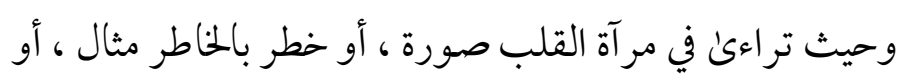
ركنت النفس إلي كيفية ، فليجزم بأن الله-تعالنى - بخلافه ؛ إذ كل

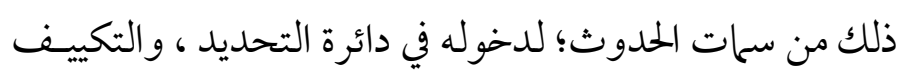

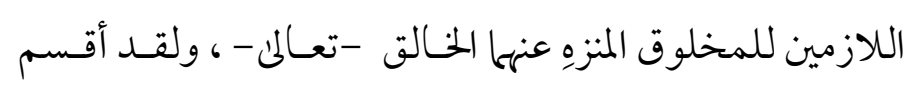

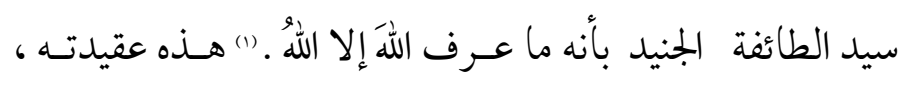
ومذهبه العقدي لكنه قد يسير مـع بعض الفـرق الأخــــ كـا سيذكر فيما بعد.

\section{شيوخه.}

تلمذ العليمي علي يد مشايخ كثيرين نظرًا لتلقيـه العلــم منـذ نعومة أظفاره، وشغفه بطلبه في إقامته، ثم اتسعت دائرة مشايخه في رحلاته المختلفة، فتعلم منهم الكثير، واقتبس من أنوار علمهم

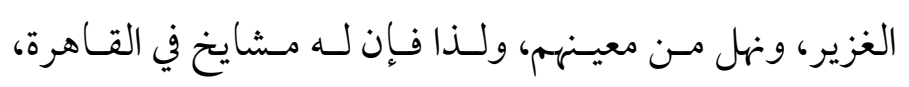

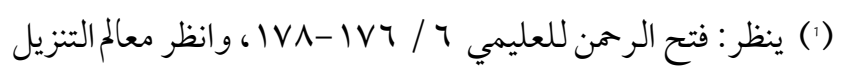

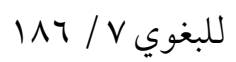


و القدس ، والرملة ، ونابلس ، والخليل فمـن أهــم شـيوخه كــا أشار إليهم في كتابه الأنس الجليل بتاريخ القدس والخليل (1). 1 - شيخ الإسلام تقي الدين أبو بكر عبد الله بن شمس الدين أبي عبد الله محمد بن الشيخ تقي الدين إسماعيل القرقشندي المقدسي

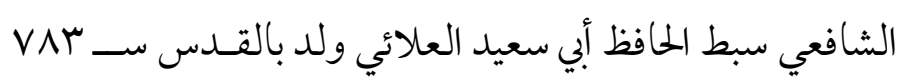
هـ واشتغل في صغره عـلي والـده ، وغـيره ، وسـمع المشايخ ،

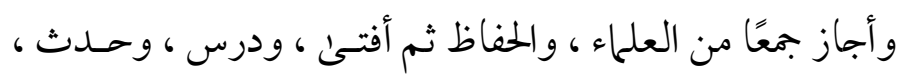

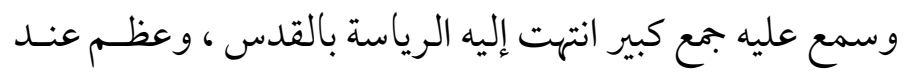

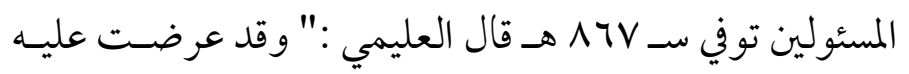

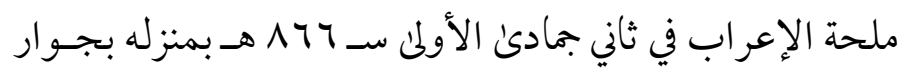

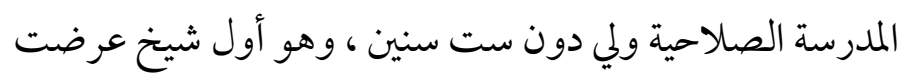
عليه وتشرفت بالجلوس بين يديه ، وأجازني بالملحة بسنده المتصل

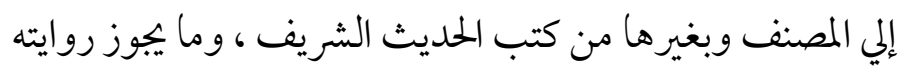
، وكتب والدي الإجازة بخطـه ، وكتـب الـشيخ خطـه الكـريم

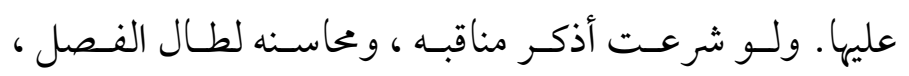

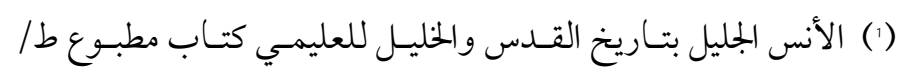

$$
\begin{aligned}
& \text { دنديس عان سـ ب أ اهـ، ، و بتحقيق / عدنان يونس عبد المجيد نباته . }
\end{aligned}
$$


وخرجت عن حد الاختصار فإن ترجمته وذكر مشايخه تحتمل الإفراد بالتأليف ، وهو أعظم من أن ينبه مثلي على فضله وعلد مرتبته فلقد كان من أعظم ححاسن الدهر توفي ليلة الخمــــ ثناني عشر شهر جمادي الآخرة سـ NT هـــ ودفن بـداخل الإيـوان الكائن بالزاوية القلندرية بتربة ماملا وكان يوما كثير المطر" "(1).

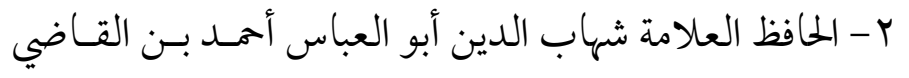

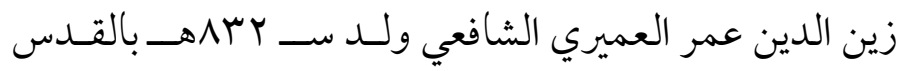

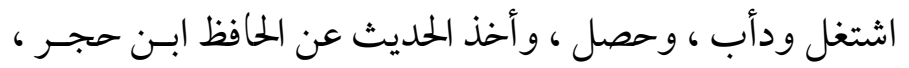

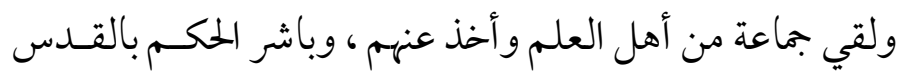

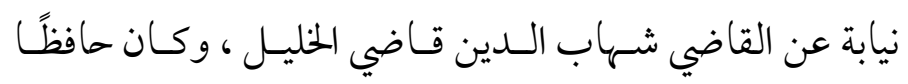

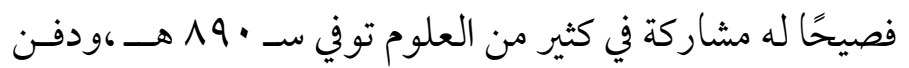
بالقدس، قال العليمي " وقد عرضت عليه في حياة الوالد قطعة

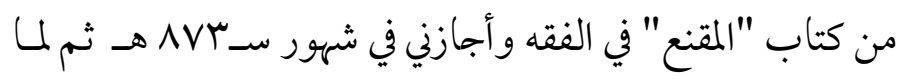

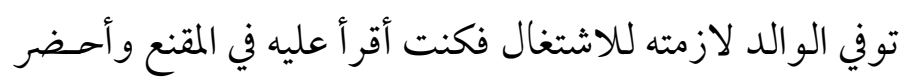
بجلس وعظه ، ودرسه بالمسجد الأقصن ، وحصلت الإجلازة منه

(1) الأنس الجليل بتاريخ القدس والخليل للعليمي r/19 19 -919، وانظر:

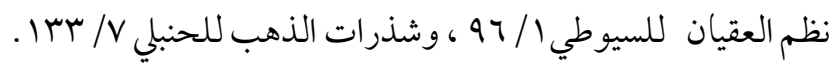


غير مرة خاصة وعامة. وكتب علي قـبره تـاريخ وفاتـه في ربيع

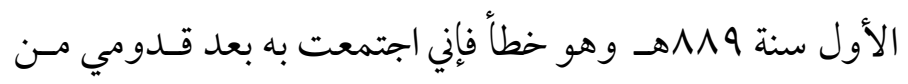
القاهرة في شوال سـ 11 1 هـ ثم علمت بوفاته وأنا مقيم بالرملة في شهر ربيع الأول سـ 119هــ وصليت عليه بالرملة).".

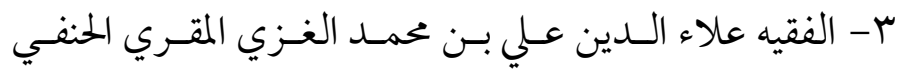
المعروف ( بابن قامو ا ) ذكر أنه لما نزل الأشرف برسباي إلي آمـد

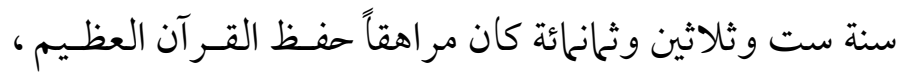
وتلنا بالسبع على العلامة شمس الدين بن عمر ان وغـيره ، أقـام

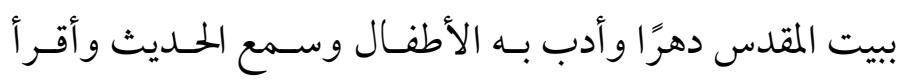
القر آن وكان - لسماع الحديث واعتنى بتحصيل الإجارة لي منـه. قال العليمي: وقد قرأت عليه القر آن - ولي نحو عشر سـنين -

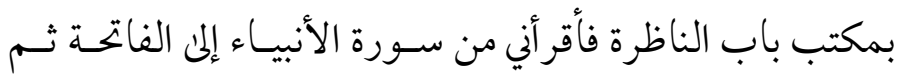
كررت ختم القر آن عليه مرات كثيرة ، وقرأت بعضه عليه برواية عاصم، و أحضرني مجلس شيخنا ابن عمران توفي في يوم الثلاثاء ثاني عشر ذي الحجة سـ • 19 هـ بالقدس (r).

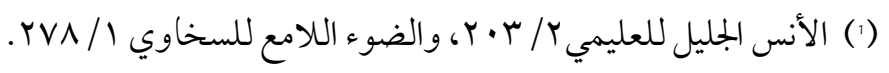
(2) الأنس الجليل بتاريخ القدس والخليل للعليمي Y / V r .
} 


$$
\begin{aligned}
& \text { ع - شيخ الإسلام كمال الدين أبو المعالي محمد بن الأمسير نـاصر }
\end{aligned}
$$

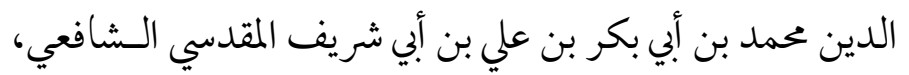

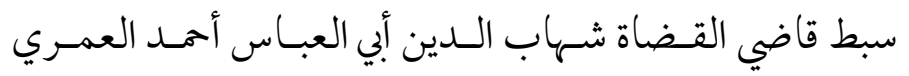

$$
\begin{aligned}
& \text { المالكي المشهور (بابن عوجان) ، ولد سـ r ب هـ بمدينة القدس }
\end{aligned}
$$

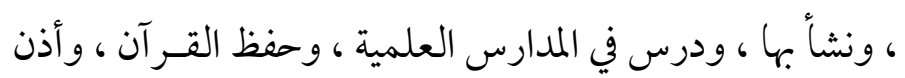

$$
\begin{aligned}
& \text { له في التدريس سـ ع عم هـ ورحهل إلي القـاهرة في هـــه الـسنة }
\end{aligned}
$$

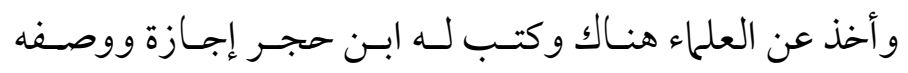

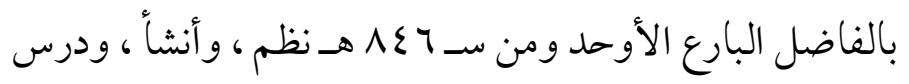

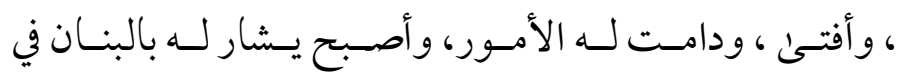

$$
\begin{aligned}
& \text { الأوساط العلمية وذكره المؤرخون إلي عام •9 هـ وله شعر رقيق لون }
\end{aligned}
$$

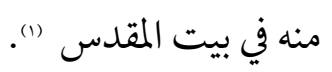

$$
\begin{aligned}
& \text { * أحيي بقاع القدس ما هبت الصبا } \\
& \text { فتلك رباع الأنس من معهد الصبا ) } \\
& \text { (وما زلت من شوقي إليها مواصلَ } \\
& \text { (") }
\end{aligned}
$$

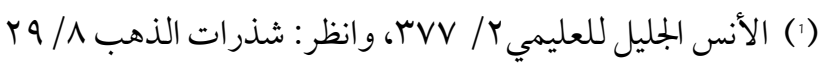

$$
\begin{aligned}
& \text { (2) ينظر : شذرات الذهب للحنبلي / • •r. }
\end{aligned}
$$


قال العليمي: عرضت عليه في حياة الو الد -رحمه الله- قطعة من

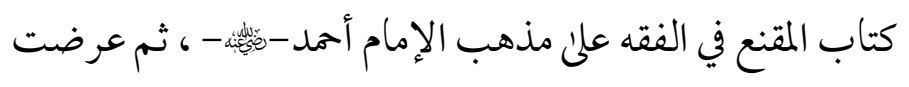
عليه مرة ثانية ما حفظت بعد العرض الأول ، وأجازني في شهور سـ 1VYهـ و حضرت بعض مجالـسه مـن الـدروس ، و الإمـلاء

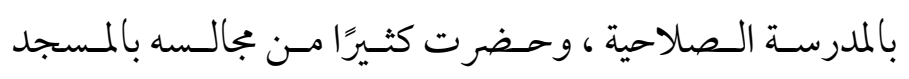

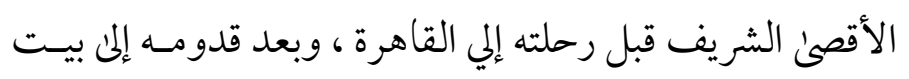
المقدس توفن سـ • 19 هـ. (1) ه - قاضي القضاة نور الدين أبو الحسن علي بن إبراهيم البدر شي

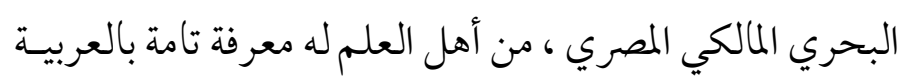
، و علم الفر ائض ، والحساب ، و الحـديث الـشريف بـاشر نيابـة

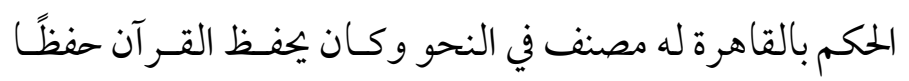
جيدًا ويكثر من التلاوة نشر العلم و انتفع به الطلبة توفن سـ NVA هـ بالقدس.قال العليمي: وقد قرأت عليه قطعة من آخر كتـاب

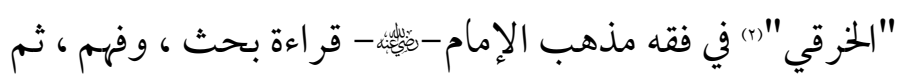
قرأت عليه قطعة من أول" المقنع " قـر اءة بحـث ، وفهـم فكـان

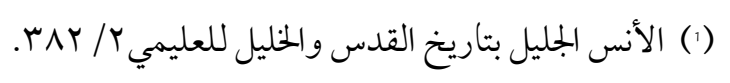

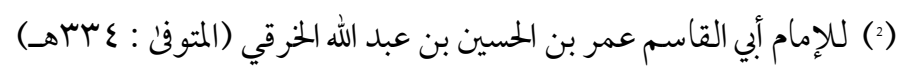

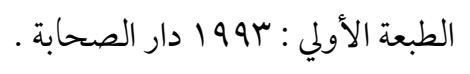




$$
\begin{aligned}
& \text { يقرر العبارة تقريرًا حسنًا لعل كثيرًا من أهل المذهب لا يقـرره ، }
\end{aligned}
$$

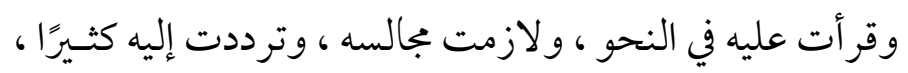

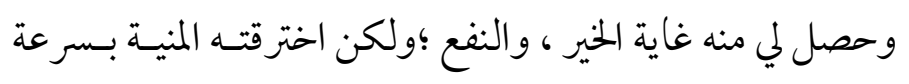

$$
\begin{aligned}
& \text { قبل بلوغ المر اد منه" (1). }
\end{aligned}
$$

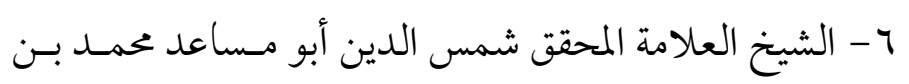

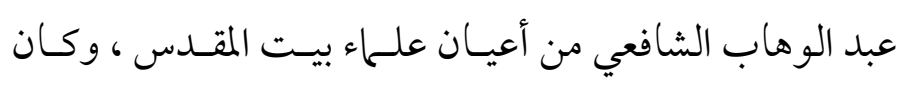
يستفيد به الناس فائدة عظيمة توفي سـ س 1 هـ بـالطاعون. قـال

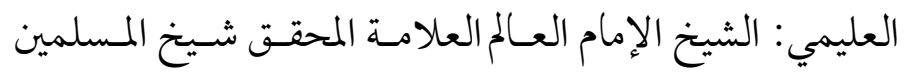

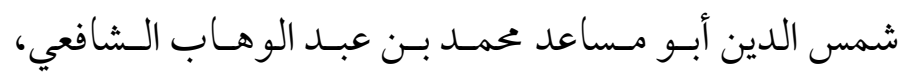

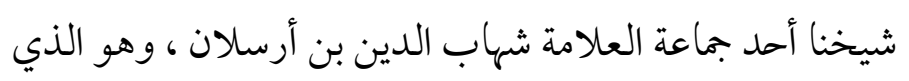

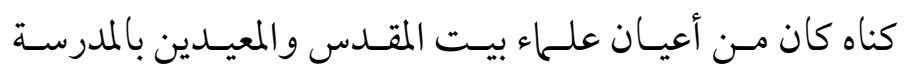
الصلاحية ، وكان يكتب علئ الفتوى عبارة حسنة انتفع الناس به وقد عرضت عليه قطعة من كتاب "المقنع" في الفقه في سـ هـ وأجازني توفي في يوم الثلاثاء سادس عشر ذي الحجة سـ هـ بالطاعون ، ودفن بالساهرة ، وكانت جنازته حافلة).".

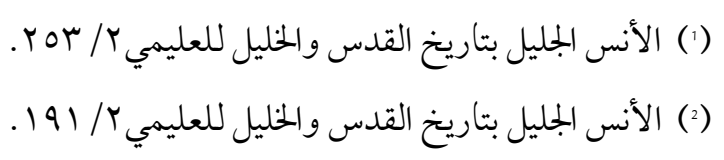


-V الشيخ برهان الدين أبو إسحاق إبراهيم بن زين الدين عبـد

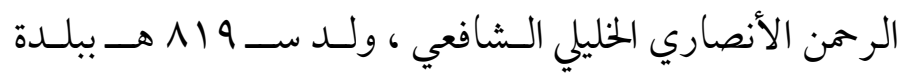

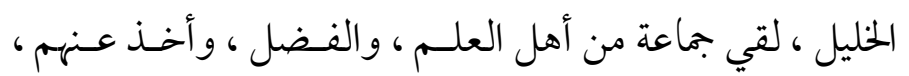
رحل إلى القاهرة ، وأخذ الحديث عن ابن حجر ، والفقه عن تقي

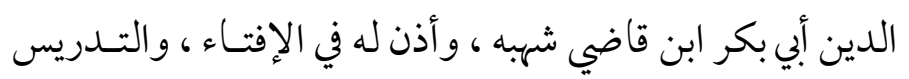
وباشر في نيابة الحكمى عن القاضي برهان الدين بـن جماعـة ، ثـمـ

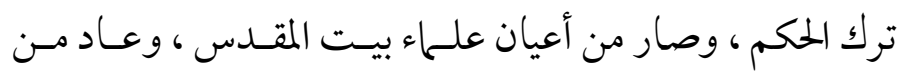

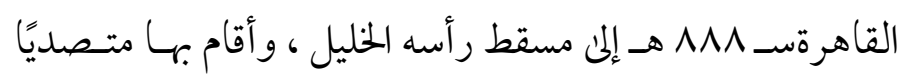

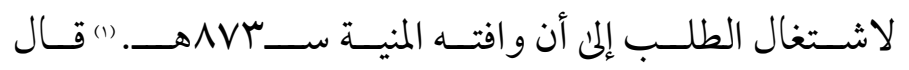
العليمي:"وقد عرضت عليه قطعة من كتاب "المقنـع" في الفقـــ بالزاوية الحنتية سـ 1 هـ هـ وأجازني بما يجوز له روايته" (() . 1- الشيخ العلامة المقري المحدث شـمس الــين أبـو عبــ الله محمد بن موسئ ابن عمر ان الغزي المقدسي الحنفي شسيخ القـراء

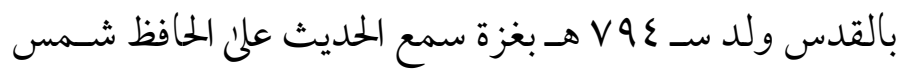
الدين الجزري ، وأخذ عنه علم القراءات ،وأجازه ، وكان رجـلاً

\footnotetext{
(1) الأنس الجليل بتاريخ القدس والخليل للعليمي / / ه .

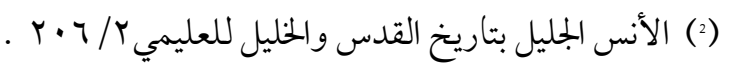


صلحاً ملازماً لقراء القر آن انتفع به الناس ، وتخرج عليه جماعـة

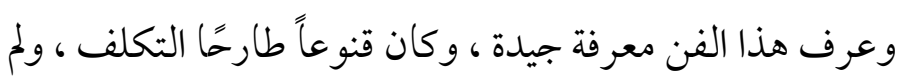

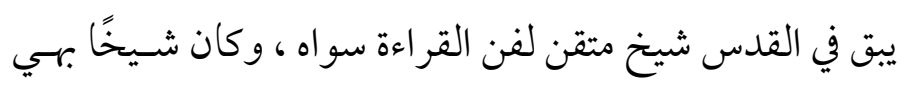

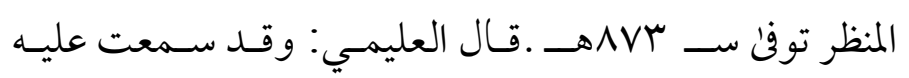
صحيح البخاري بقراءة القاضي شهاب الدين بن عبيد الشافعي

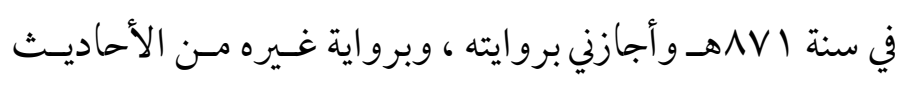

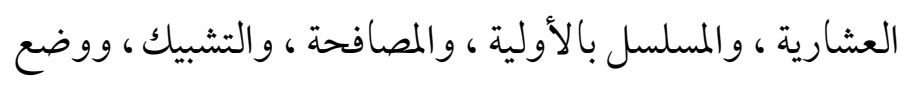

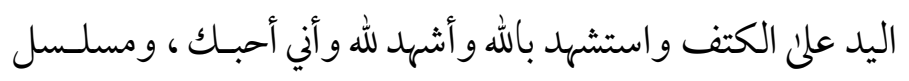

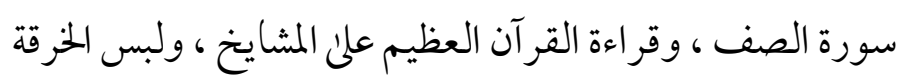

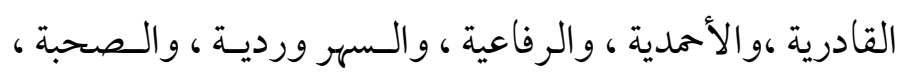

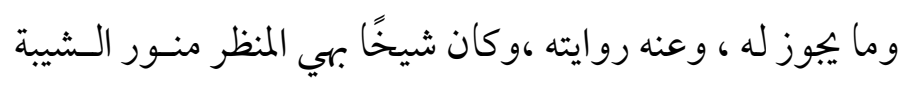

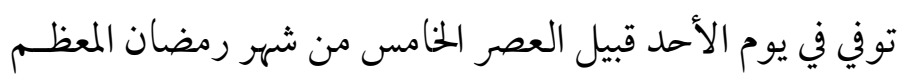
سـ مAVI ودهـ ودفن من الغد بمقبرة ماملا").

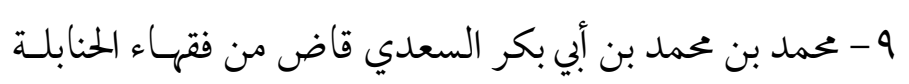

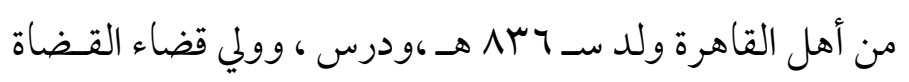

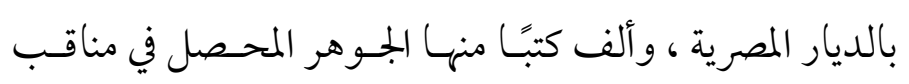

(1) الأنس الجليل بتاريخ القدس والخليل للعليمي / • ب . . 
الإمام أحمد خخطوط قال السخاوي :كتـب بخطـه مـن تصانيفه

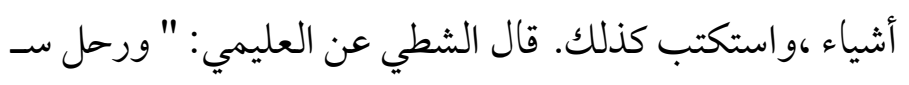

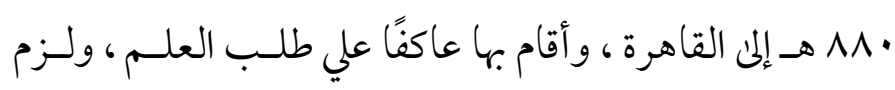

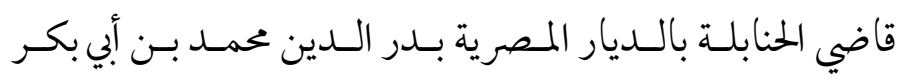

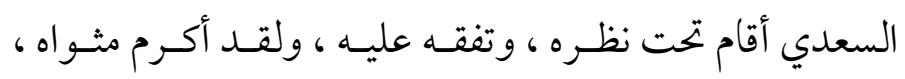
ومكث بالديار المصرية نحو عشر سنين(1). وعلي هذا يكون هؤلاء هم أساتذة العليمسي وطليعـة شـيوخه ،

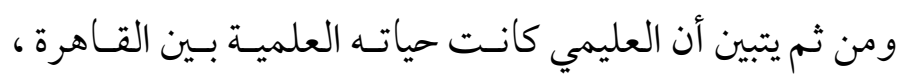
والقدس فقي القاهرة سنوات عشرة، وفي القدس بقية حياته بين المسجد الأقصن -- و المدرسة الصلاحية ، ولعله بعد عودته مـن القاهرة إلي القدس ظل بها حتي وافته المنية . تلاميذه :

لم تــذكر الكتـب التـي ترجمـت للعليمسي الآخـذين عنـه ،

والمتتلمذين علي يديه ، ما خلا ما ذكره جـار الله بـن فهـد المكي لـي الشافعي المسند المؤرخ ، المتوفن سـع 90هـ ، حيث ذكر أنه أخـذ عن العليمي بعض مؤلفاته ، وأجاز له روايتها .

(1) الأنس الجليل بتاريخ القدس والخليل للعليمي / V ، و الضوء اللامع

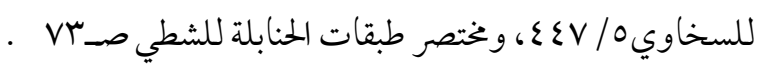




$$
\begin{aligned}
& \text { وأفاد الدكتور عبد الـرحمن العثيمسين : أنـهـ وقـف علي }
\end{aligned}
$$

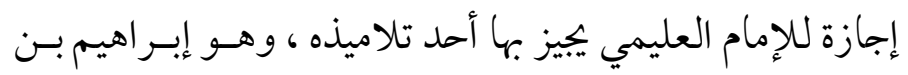

$$
\begin{aligned}
& \text { خليل القاقونئ الحنبلى بكتاب ( التسهيل ) فن الفقه الحنبلئ . }
\end{aligned}
$$

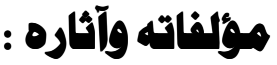

خلف العليمي للمكتبة الإسلامية ، كتبًا ذاخرة في خختلف وارهـ

$$
\begin{aligned}
& \text { الفنون ـ في التاريخ ، والتفسير ، و التراجم ، والفقه . } \\
& 1 \text { - الأنس الجليل بتاريخ القدس والخليل (1) . . } \\
& \text { r - فتح الرحمن في تفسير القرآن } \\
& \text { ب- المنهج الأحمد في تراجم أصحاب الإمام أحمد (r) }
\end{aligned}
$$

\section{هذهببه الفقهي:}

كان العليمي يسير علي المذهب الحنبلي ،هذا التفسير من التفاسير

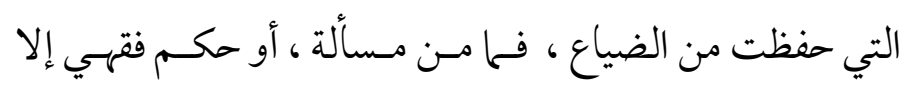

(') الأنس الجليل بتاريخ القدس والخليل للعليمي كتاب مطبوع ط/

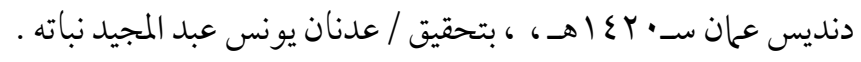

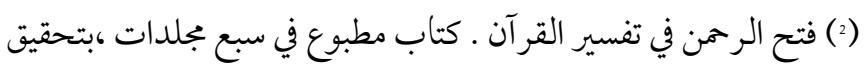

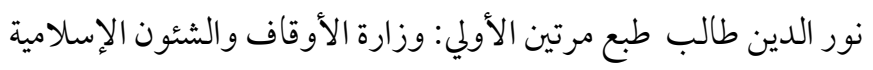

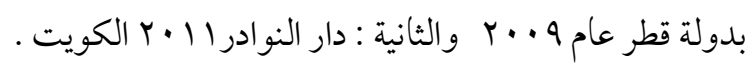

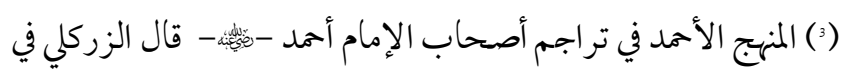

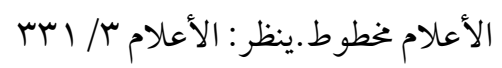


وذكر مذهب الحنابلة في تفسيره ، وفي بعض الأحيان ينفرد بذكر

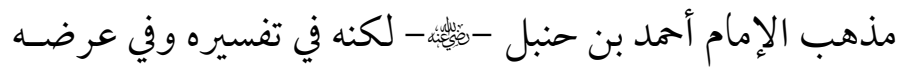

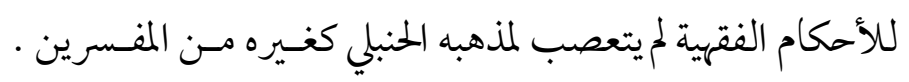
وسيتضح هذا في أثناء الكلام علي موقفه مـن الأحكـام الفتهيـة بشيء من التفصيل. ثناء العلمهاء عليه :

$$
\text { أثنى العلماءُ على إمامنا خيرًا : }
$$

قال عنه الحافظ السخاوي : أمثلُ قضاة القدس ، حسن السيرة ،

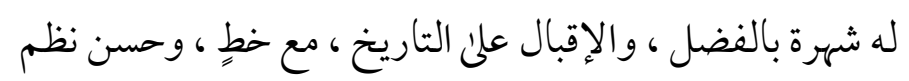

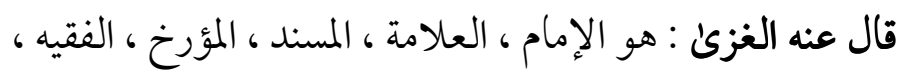
المتفنن فن سائر العلوم ، المتحلن بقلائد المنطوق و المفهوم ......... ثم قال : الخطيب ، الفقيه ، المحدث ، الأثري . وفاته: توفن - رحمـه الله - بييـت المقـدس سـ

$$
\text { (1) - ورضى عنه }
$$

(1) الأعلام للزركلي / ابr . 


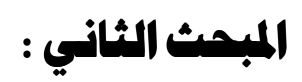

$$
\begin{aligned}
& \text { تعريف النسفة، وأهميته ، وشتروطه. } \\
& \text { قبل الحديث عن الناسخ والمنسوخ في تفسير العليمي } \\
& \text { لابد أن نعـرف النسخخ ، وأهميتـه، وطـرق معرفتـه ، وشروط } \\
& \text { الناسخ والمنسوخ } \\
& \text { أولا: تمريف النسجة: }
\end{aligned}
$$

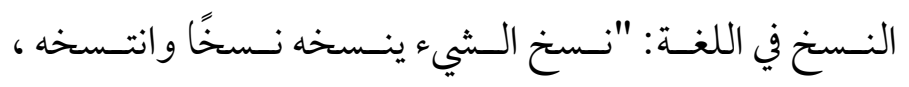

$$
\begin{aligned}
& \text { واستنسخه اكتبه عن معارضه، النسخ: اكتتابك كتابًا عن كتـاب } \\
& \text { حرفًا بحرف، والأصل "نسخه" والمكتوب عنه (نسخة) ؛لأنه أنس } \\
& \text { قام مقامه ، والكاتب: ناسخ ، ومتتسخ، والاستنساخ: كتـب }
\end{aligned}
$$

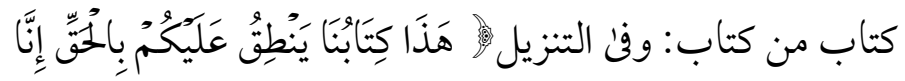

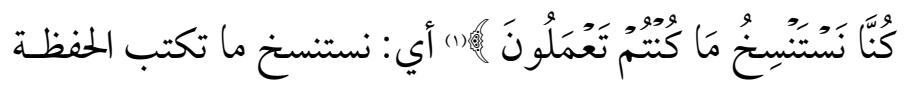

$$
\begin{aligned}
& \text { فثبت عند الله. } \\
& \text { والنسخ: إبطال الشيء وإقامة آخر مقامه: وفي التنزيل لِمَا تَنَْخْ }
\end{aligned}
$$

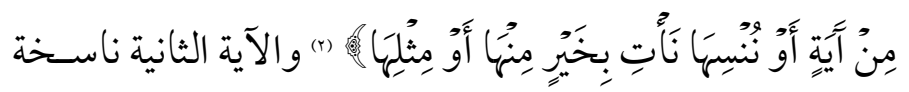

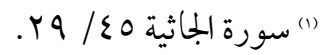

$$
\begin{aligned}
& \text { (1) سورة البقرة r/ ז ؟ 1 . }
\end{aligned}
$$




$$
\begin{aligned}
& \text { والأولي منسوخة، ونسخ الآية بالآية: إزالة مثل حكمها. والنسخ } \\
& \text { نقل الـشيء مـن مكـان إلي مكـان، والعـرب تقــول: "نَسَخَتُ }
\end{aligned}
$$

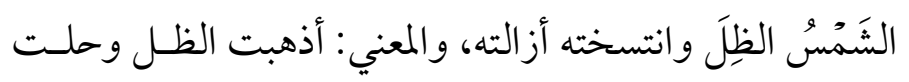

$$
\begin{aligned}
& \text { محله" }
\end{aligned}
$$

والنسخ اصطلاحها: "هو : رفع الحكم الشرعي بــليل شرعي متراخ عنه ()( ومعني رفع الحكم الـشرعي: قطع تعلقـه بأفعـال المكلفين لا رفعه هو، فإنه أمر واقع ، والو اقع لا يرتفع.

\section{ثانيكا: أهمية النسخجة}

يقول الزرقاني، ولهذا المبحث أهمية خاصة وذلك من وجوه:

أولا: أن أعداء الإسلام من ملا حدة ، ومبـشرين ، ومستشرقين ومدين

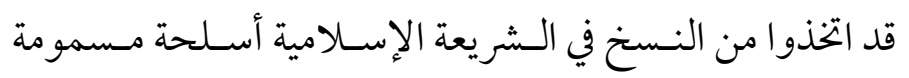

، طعنو ابها في صدر الدين الحنيـف، ونـالوا مـن قدسـية القـرآن الكريم، ولقــ أحكمــو اشراك شـبهاتهم، واجتهـدوا في تـرويج

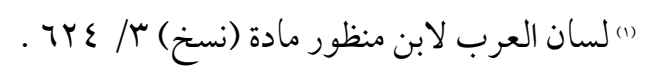

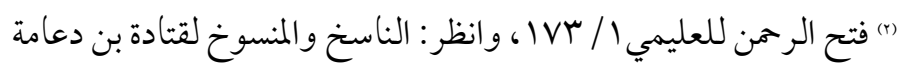

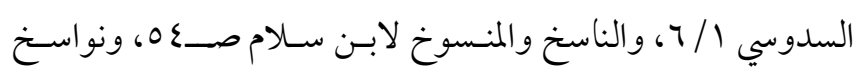

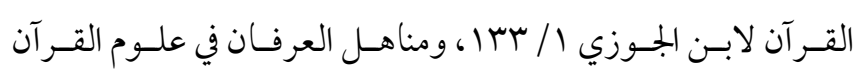

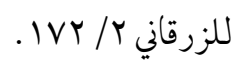


مطاعنهم حتىلى سحرو اعقول بعض المتتسبين إلي العلــم والـدين من المسلمين، فجحدوا وقوع النسخ وهو واقع، وأمعنو افي هذا الجحود الذي ركبو اله أخششن المر اكـبـ مـن تمحـلات سـاقطة، وتأويلات غير سائغة. ثانيتا: أن الإلمام بالناسخ ، والمنسوخ يكشف النقاب عـن سـير التشريع الإسلامي، ويطلـع الإنسان عـلن حكمـة الله في تربيتـه

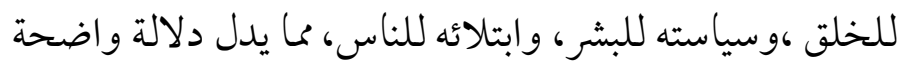

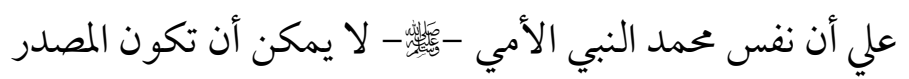

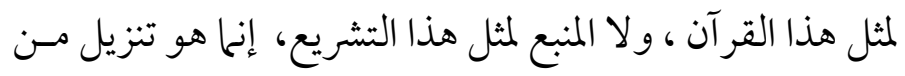
حكيم حميد. ثالثثا: أن معرفة الناسخ والمنسوخ ركن عظيم من فهم الإسلام، وفي الاهتداء إلي صحيح الأحكام ، خصوصًا إذا ما وجدت أدلة متعارضة لا يندفع التناقض بينها إلا بمعرفة سابقها من لاحقها ، وناسخها من منسوخها، ولهذا كان سـلفنا الـصالح يعنسون بهــه الناحية يحذقونها ويلفتون أنظار الناس إليها، ويحملـونهم عليها،

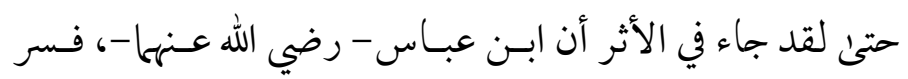

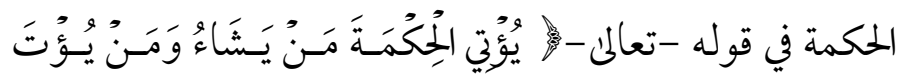




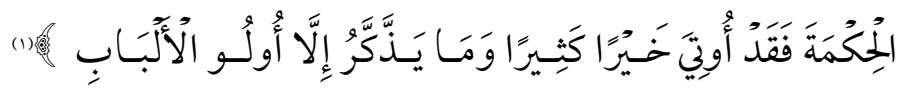

بمعرفة الناسخ والمنسوخ، ومككمه ومتشابهه ، ومقدمه ومؤخره ، وحلاله وحر امه وأمثاله ب(i).

وورد أن عليًّا - كـرم الله وجهـه- دخل المسجديد فإذا رجـل يخوف الناس فقال: ما هذا؟ قالو ارجل يذكر الناس، فقال: ليس برجل يذكر الناس؛ ولكنه يقول أنا فـلان بـن فـلان فاعرفوني،

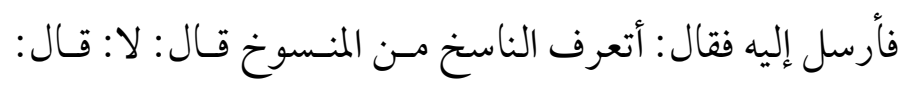
اخرج من مسجدنا ، ولا تذكر فيه، وروي أنه - كرم اللهو وجهـ

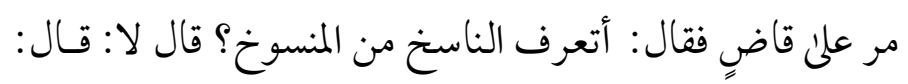

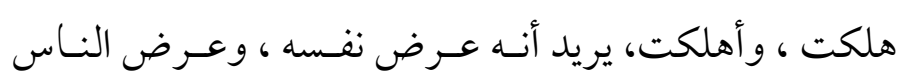

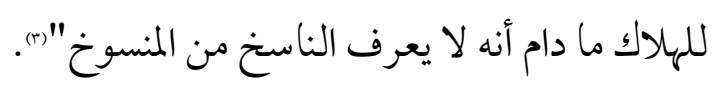

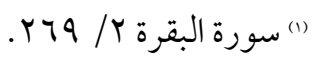

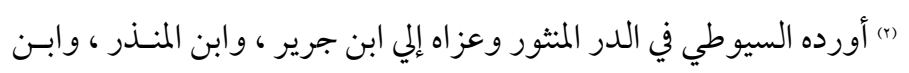

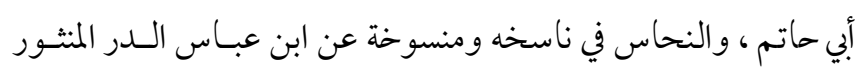
$.77 / r$ "(1) ينظر: مناهل العرفان في علوم القرآن للزرقاني / / 1 1 - 1 1 بتصرف يسمر 


\section{ثالثا: طرق معرفة النسخ:-}

لابد في تحقيق النسخ مسن ورود دليلـين عـن الـشارع ،

وهما متعارضان تعارضًا حقيقيًا لا سبيل إلى تلافيه ، فـلا يمكـن

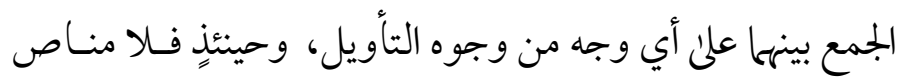

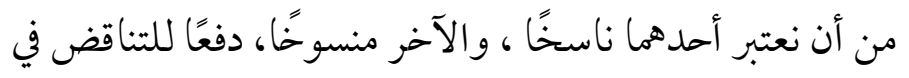

كلام الشارع الحكيم ؛ ولكن الدليلين يتعـين أن يكـون ناسـخًا، وأيها يتعين أن يكون منسوخًا.

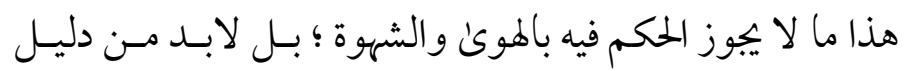

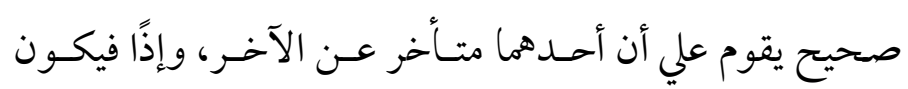
السابق هو المنسوخ ،و اللاحق هو الناسخ، ولنا إلي هـــا الــليل

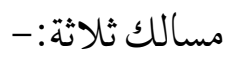

1 - أن يكون في أحد النصين ما يدل على تعين المتأخر منها نحو

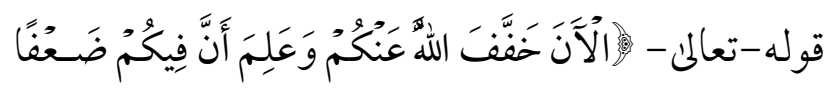

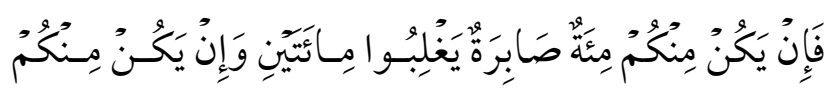

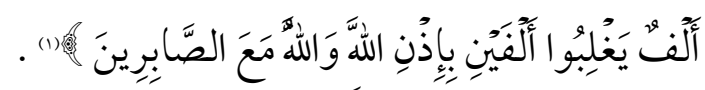

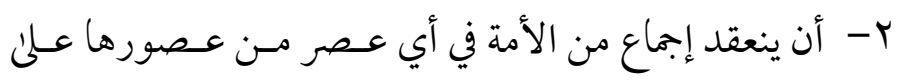
تعين المتقدم من النصين من المتأخر منها.

(1) سورة الأنفال 1/ 17. 
r- أن يرد من طرق صحيحة عن أحد من الصحابة مـا يفيـد

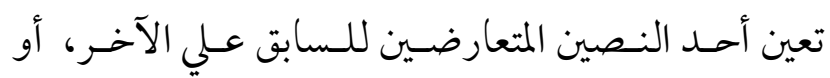

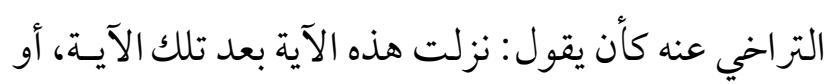

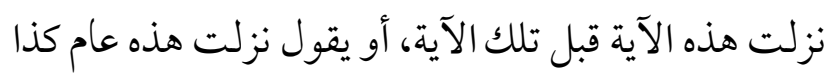

، وكان معروفًا سبق نزول الآيـة التي تعارضهها ، أو كـان

$$
\text { معروفًا تأخرها عنها" (1). }
$$

رابعا: شروط الناسخ والمنسوخ :

أولا: شروط الناسخة:

1 - أن يكون منفصلاً من المنسوخ منقطعًا منه، فإن كان متصلًا

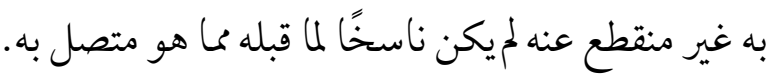

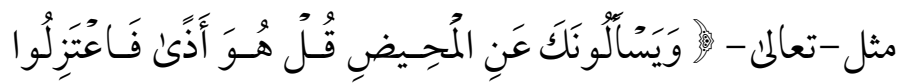

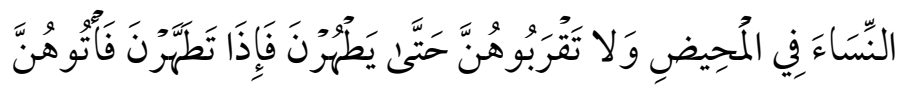

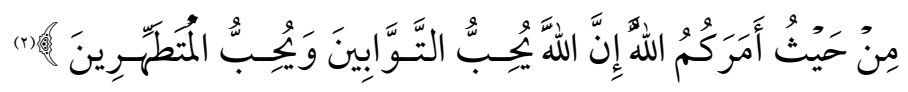

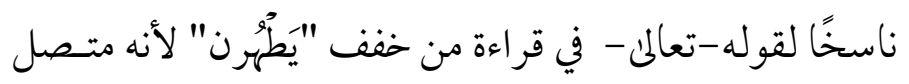

به، فالأول: يراد به ارتفاع الدم.والثاني: التطهير بالماء.

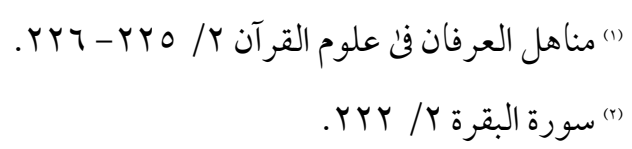




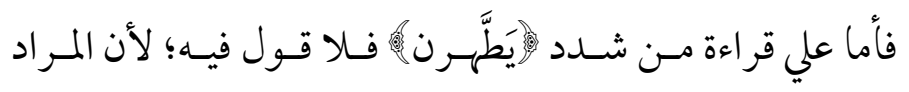
بالأول حتي يطهرن بالماء (فإذا تطهرن بالماء

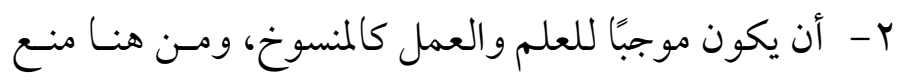
نسخ القرآن بخبر الآحاد؛ لأن أخبار الآحاد توجب العمـل ولا توجب العلم والقرآن يوجبها جميعًا.

r- أنه يجوز أن ينسخ الأثقل بالأخف، كقولـه-تعـالي - إِ إن

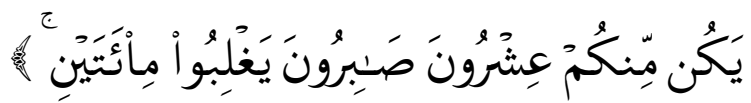

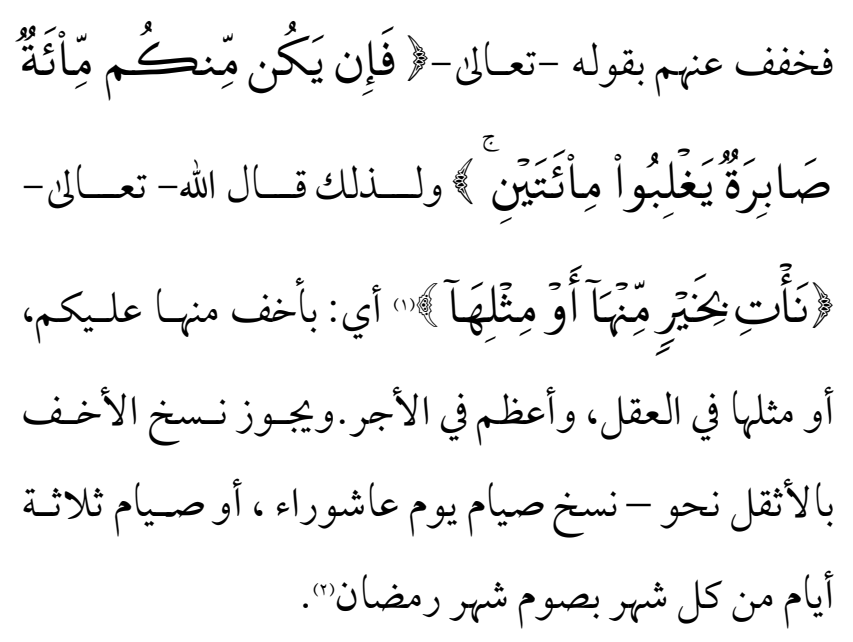

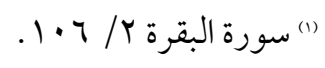

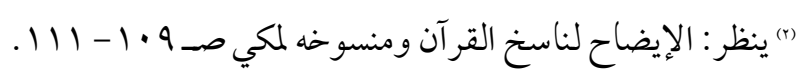


ع - أن يكون ثبوت الملكم الناسخ مشروعًا كثبـوت المنسوخ،

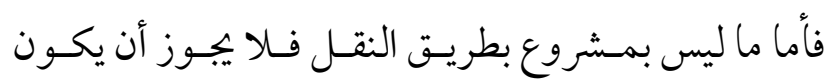

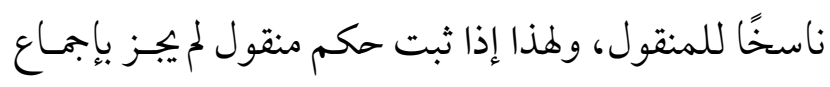

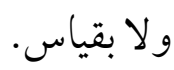

0- أن يكون الطريق الذي ثبت به الناسخ مثل الطريق الـذي

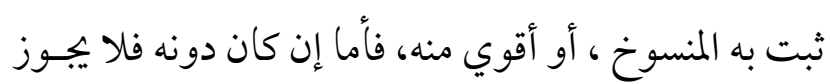

أن يكون الأضعف ناسخًا للأقوى" "(1).

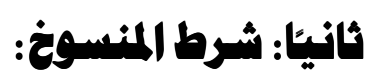

1- ويشترط في المنسوخ أن يكون غير متعلق بوقف معلوم، أنسون

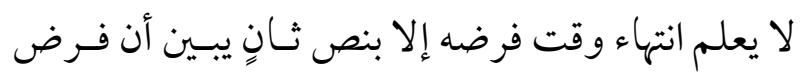

الأول إلي الوقف الذي فرض فيه الثاني.

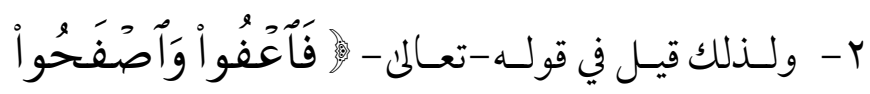

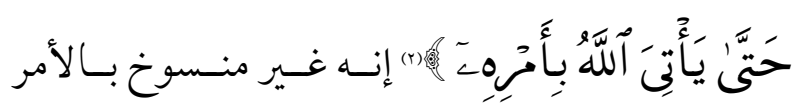

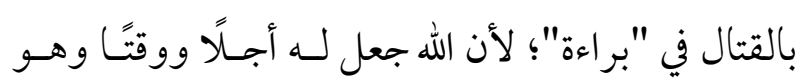

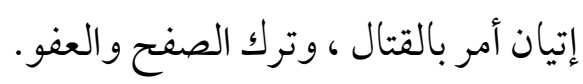

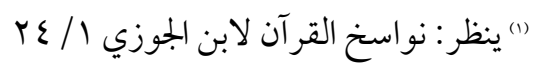

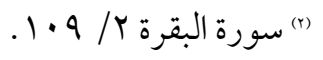


وإنما يكون منسوظًا بالقتال لو قال: فاعفوا واصفحوا أمرًا غير

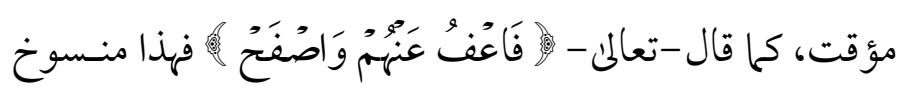

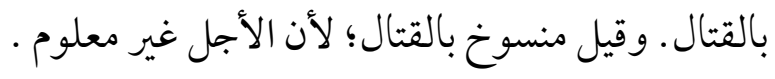

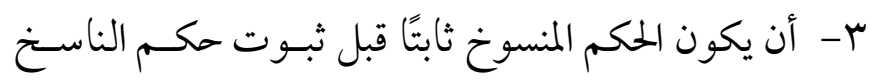

$$
\text { وذلك يقع بطريقتين: }
$$

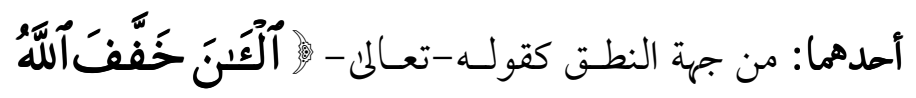

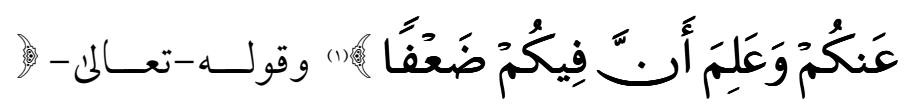

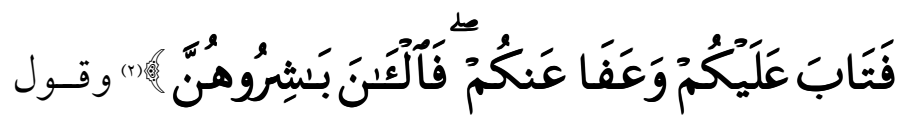

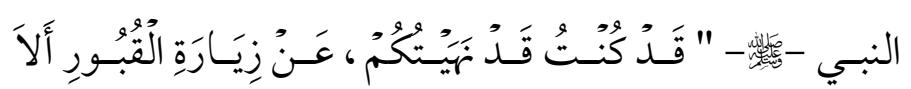

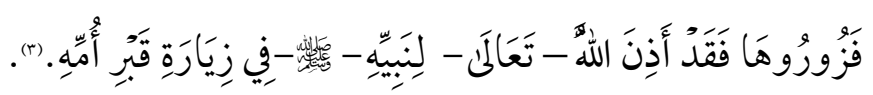

$$
\begin{aligned}
& \text { (1) سورة الأنفال 1/ } 77 .
\end{aligned}
$$

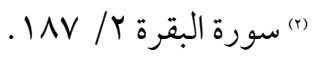

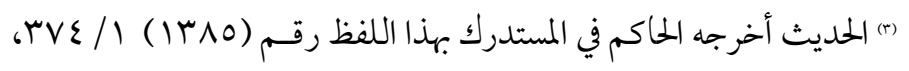

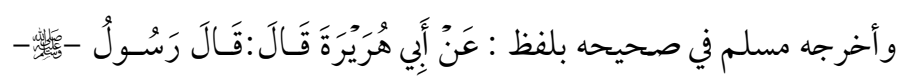

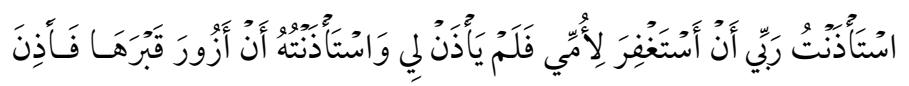

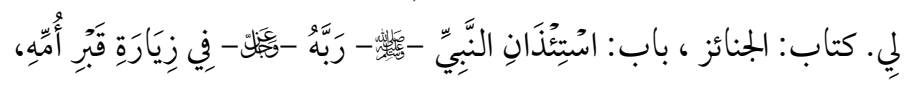

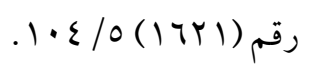




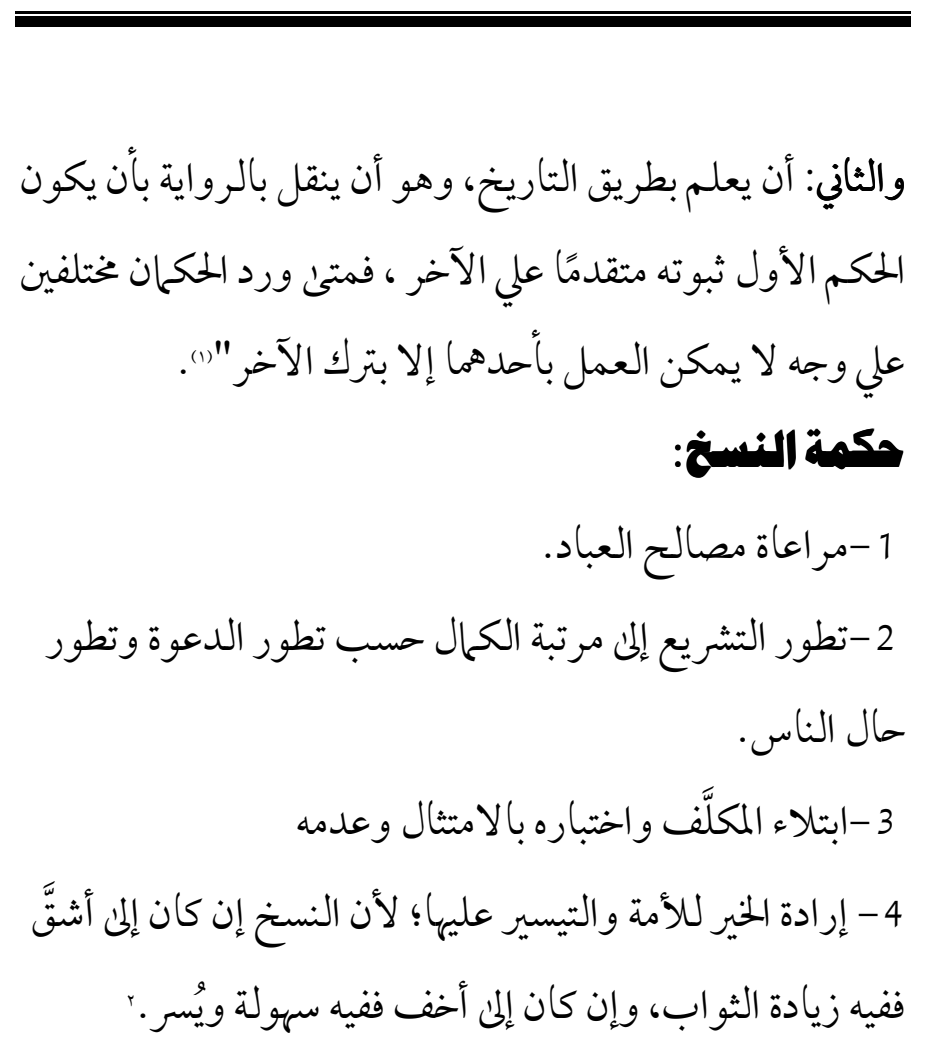

ففيه زيادة الثواب، و إن كان إلى أخف ففيه سهولة ويُسر.

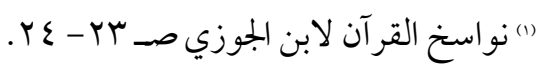

$$
\begin{aligned}
& \text { 2مباحث في علوم القران / مناع خليل القطان ت · rع اهـ مكتبة المعارف } \\
& \text { للنشر والتوزيع - الطبعة الثالثة البع اهـ -.... }
\end{aligned}
$$




$$
\begin{aligned}
& \text { المبمث الثالث: }
\end{aligned}
$$

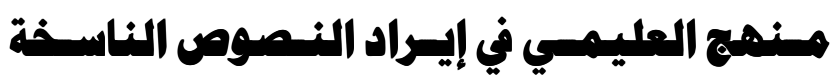

$$
\begin{aligned}
& \text { والمنسوخة من القرآن الكريميم } \\
& \text { وفيه خمسة مطالب. } \\
& \text { المطب الأول: ذكره الناسخ والمنسوخ في الآية . } \\
& \text { المطاب الثاني: ذكره الآيات المختلف فيها بين النسخ وعدمه. } \\
& \text { الامطلب الثاله: ذكره المُخْتَكَفْ في ناسِخِهِ القر آنْ ، أم السنة. } \\
& \text { المطالب الرابع: إكثاره من ذكر المنسوخ بآية السيف أو القتال. } \\
& \text { المطلب الخامس: نصه علي عدم وجود نسخ في السورة.وهو قليل } \\
& \text { المطاب الأول: ذكره الناسخ والمنسوغ في الآية . }
\end{aligned}
$$

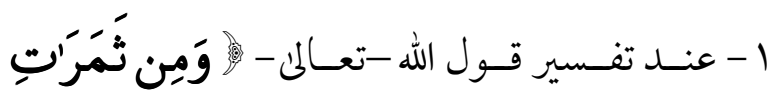

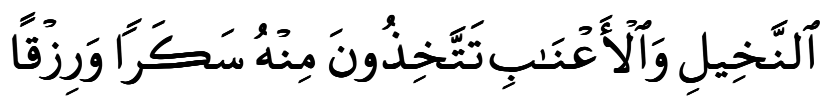

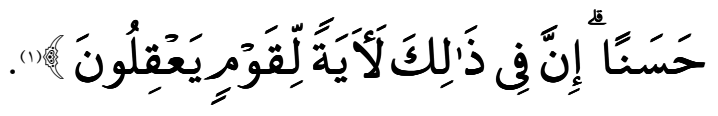

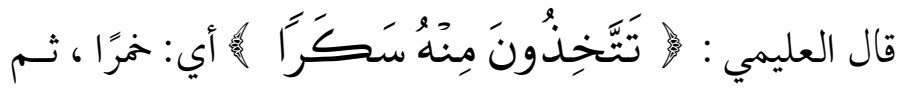

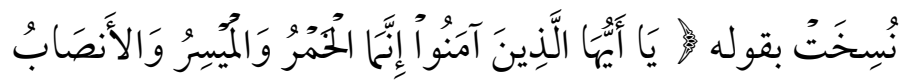$$
\text { (1) سورة النحل } 7 \text { / TV. }
$$ 


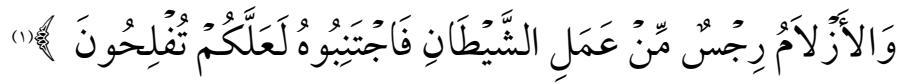

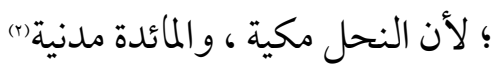

ذكر العليمي الآية المنسوخة ، وذكر الآية الناسخة ، وذكر أن آية

النحل سابقة لآية المائدة ـ لكن هناك خلاف بين العلماء في نسخ

الآية من عدم نسخها . فهناك من العلم)ء من جزم بنسخها ، وهـو

قول ججاهـد، وابـن جبـير، و الـشعبي (r). وهنـاك مـن المفسسرين

و العلماء من منع نسخها وقال :بأنه خبر وليس بأمر .

فيقول مكي : والذي عليه أهل النظر : إن هذا لا يجوز نسخه

؛ لأنه خبر، وليس بأمر فينسخ ، وإنما نزلت الآيـة قبـل أن تحـرم

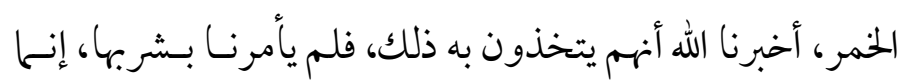

هو خبر عما أنعم عليهم به(s).ثم علل مكيُ كـلام مـن قـال بأنهـا

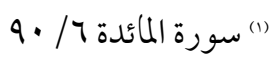

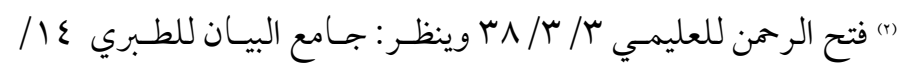

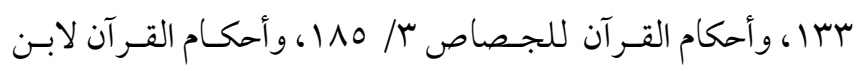

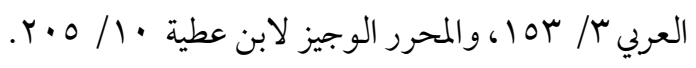

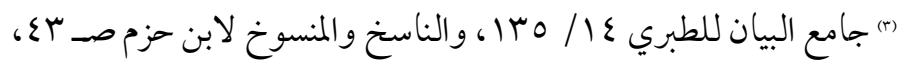

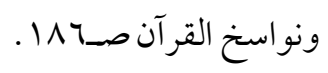

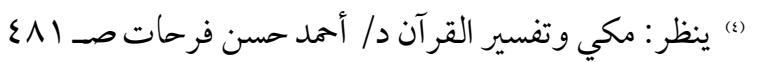




$$
\begin{aligned}
& \text { منسوخة بقوله: من تأول أن السكر في الآية: متور الأعاجم قال: } \\
& \text { هو منسوخ بتحريم الحمر في المائدة") وغيرها). }
\end{aligned}
$$

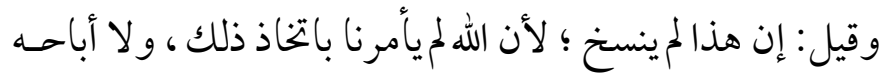

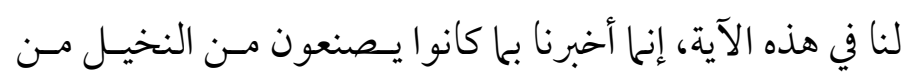
السكر الذي حرمه الله في المائدة.

وقيل: إن هذا الخبر وشبه جائز نسخه، والأخبار علي ضربين.

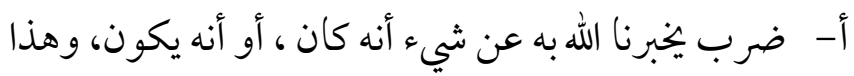

$$
\text { لا يجوز نسخه. }
$$

ب- الضرب الثاني: من الحبر هو الذي يجوز نسخه: وهـو أن

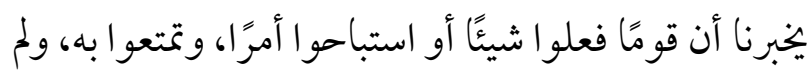
يحرم ذلك عليهم، ثم يخبرنا الله أنه محرم علينا.

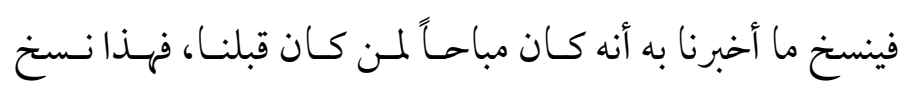
المسكوت عنه من فهم الخطاب لأنه قد فهم من قوله: آتَتَّخِذُونَ

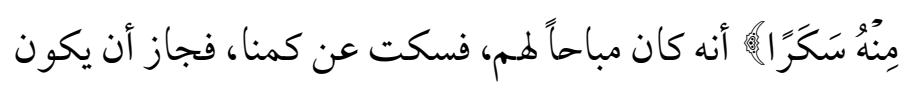

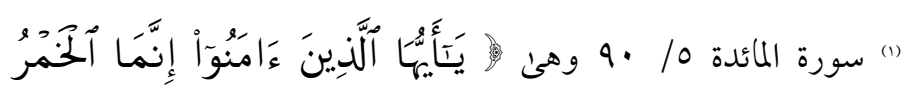

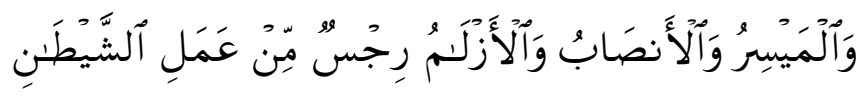

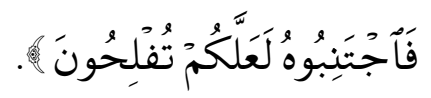


مباحاً لنا أيضاً، ثم نسخ جواز إباحته لنا بالتحريم في المائدة، ولو

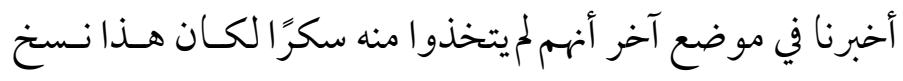

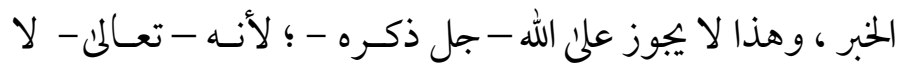

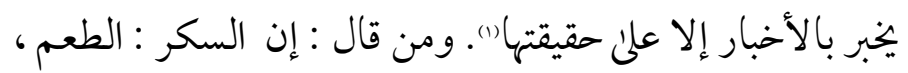
وهو قول : أبي عبيدة ، أول قال : السُكر : ما سدَّ الموع ، فلائيوز

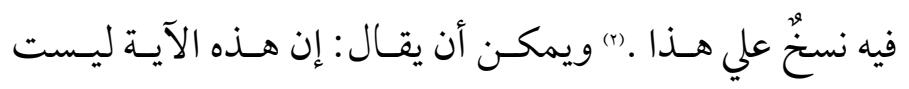
بمنسوخة، ويكون المعني، أنه خلق لكم هذه الـثار لتنتفعو ابها

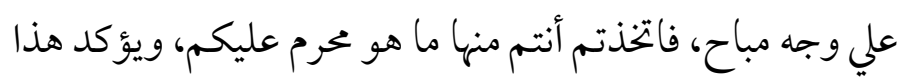
أنها خبر ، والأخبار لا تنسخ، وليس في الآيـة مـا يقتضي إباحسة السكر، إنما هي معاتبة وتوبيخخ" (1). وقيل: إن السكر المنحل بلغة الحبشة، مروي عن ابن عباس.

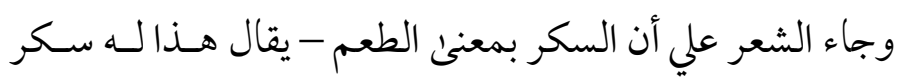
أي: طعم ، وأنشدوا: جعلت عنب الأكرمين سكراً. (9) الطعال

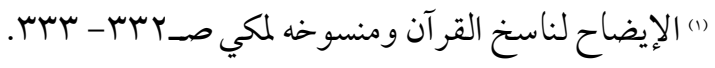

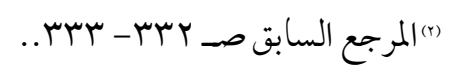

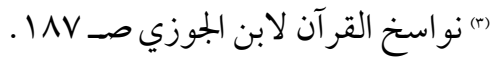

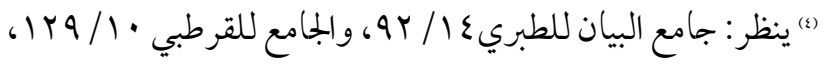

$$
\begin{aligned}
& \text { وقائل هذا البيت هو جندل بن مثنى الطهوري، وفي رواية عرض الأكرمين. }
\end{aligned}
$$




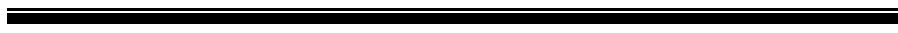

$$
\text { قال أبو عبيدة: فعلي هذين القولين الآية محكمة"). }
$$

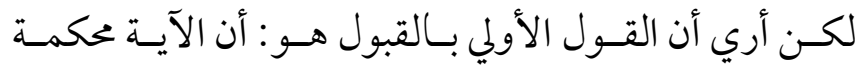

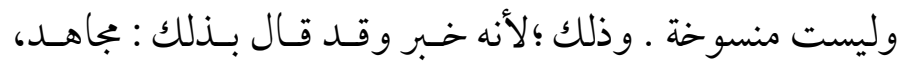

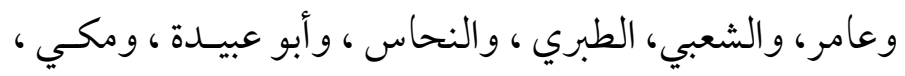

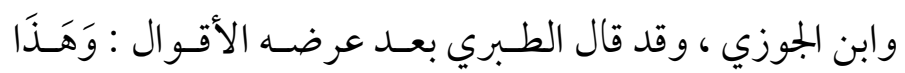

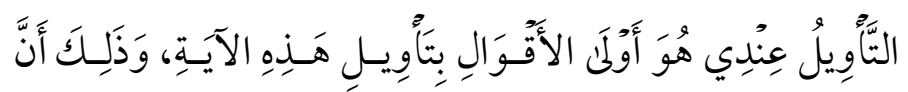

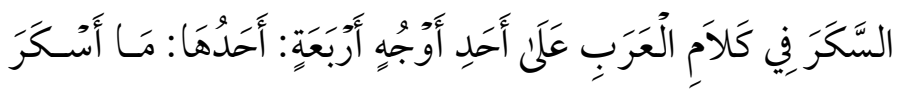

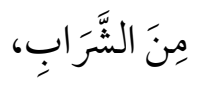

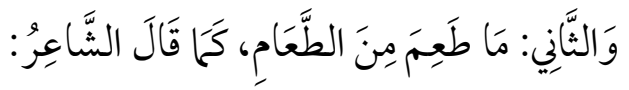

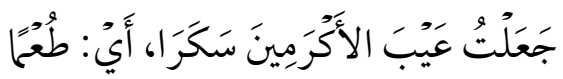

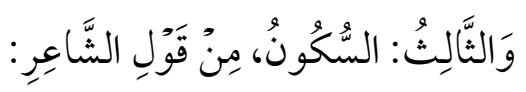

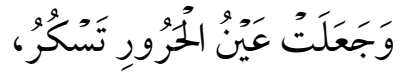

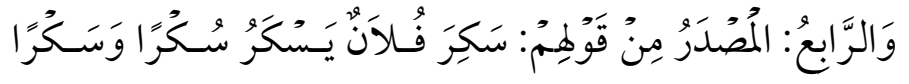
وَسَكَرَا.

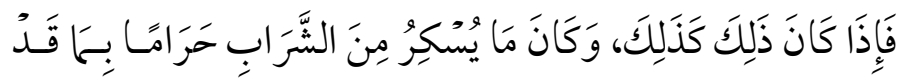

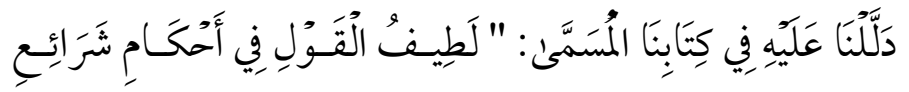

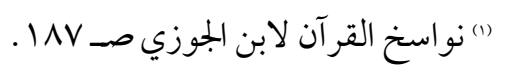




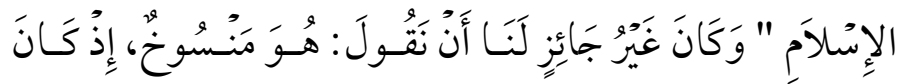

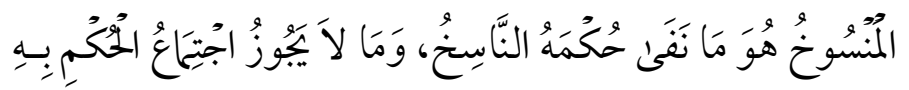

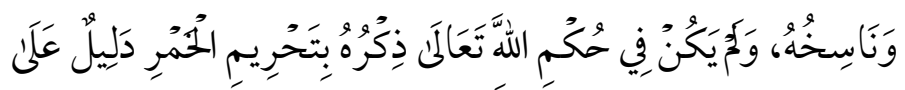

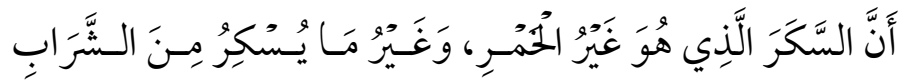

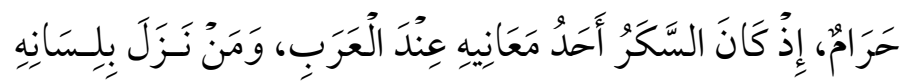

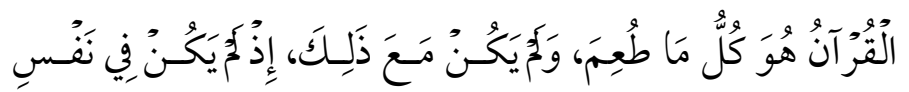

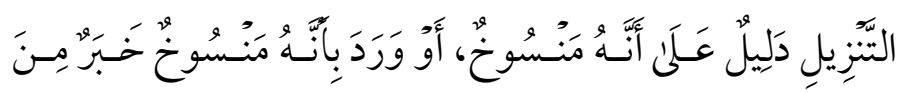

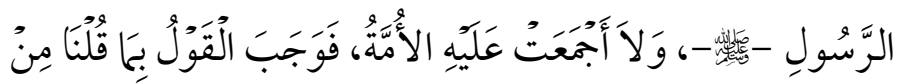

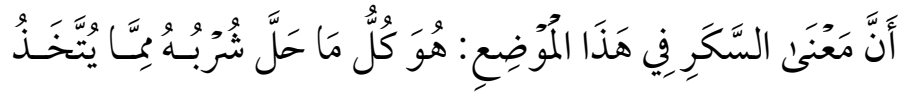

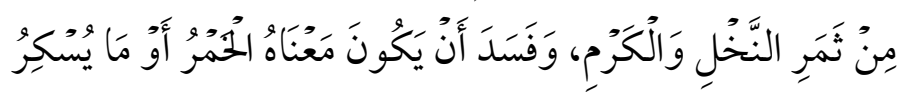

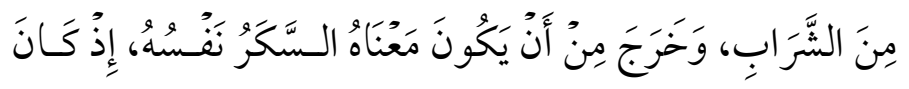

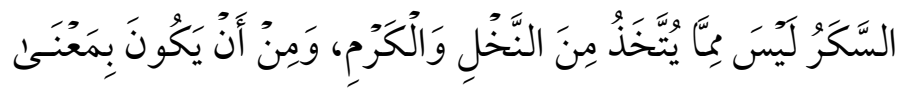

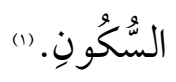

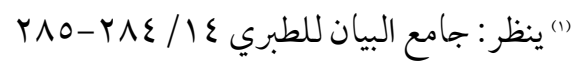




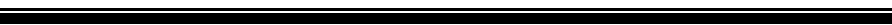

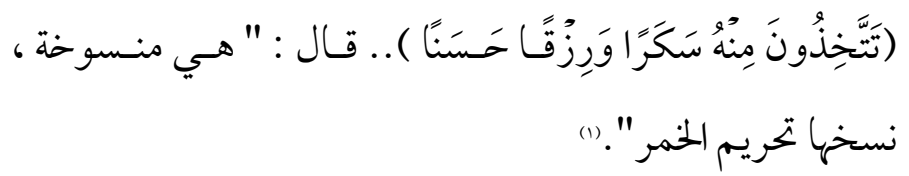

1 تفسير جامع البيان / للطبري -ج ع 1 ، ص rVq - دار هجر للطباعة

والنشر والتوزيع - الطبعة الأولى rrع اهـ - 1 + . rم - تحقيق الدكتور

عبد الله بن عبد المحسن التركي. 


\section{المطاب الثاني : ذكره الآيات المفتلف فيها}

\section{بتن النسخ وعدهمه.}

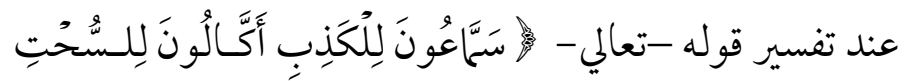

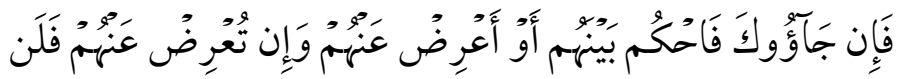

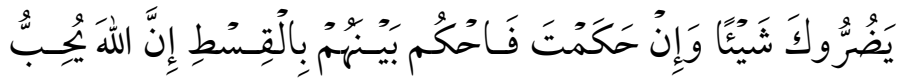

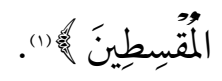

يقول العليمي : واختلفوا في حكم الآيـة اليـوم ، هـل للحـاكم الحيار في الحكم بين أهل الذمة إذا تحاكمو ؟ فقال أكثر أهل العلم

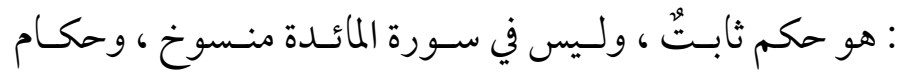

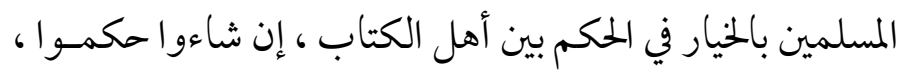

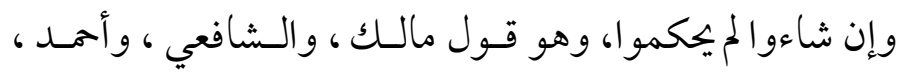

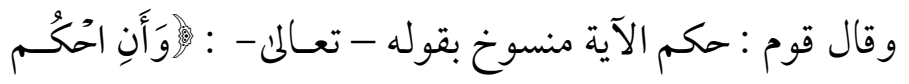

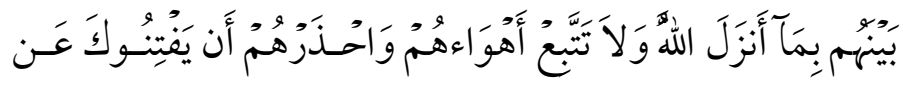

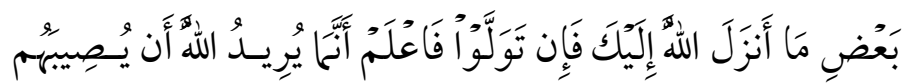

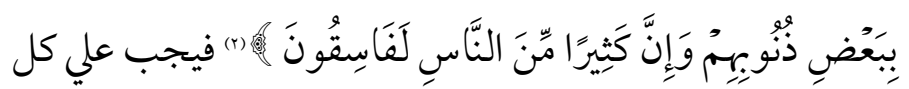
حاكم المسلمين الحكم بينهم، وهو قول أبي حنيفة و أصحابه ، فأما

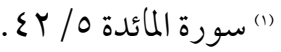
(9) 


$$
\begin{aligned}
& \text { إذا كانـت الخـصومة بـين مسلم وذمي ، فيجـب الحكــم بيـهنها }
\end{aligned}
$$

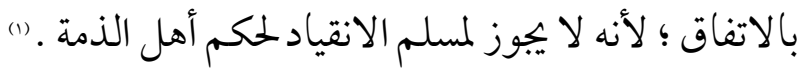

$$
\begin{aligned}
& \text { هذا ما ذكره العليمي ولميزيزم بقول مـن الأقـوال .وهـــهـ الآيــة }
\end{aligned}
$$

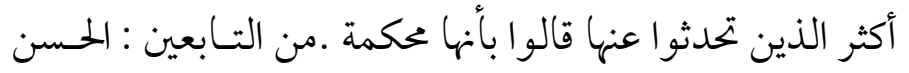

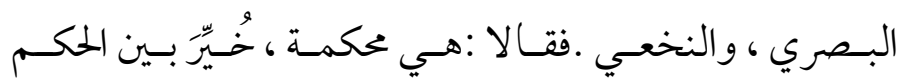

$$
\begin{aligned}
& \text { والإعراض. (") }
\end{aligned}
$$

وقال بنسخها من التابعين () : مجاهد ، وسعيد بن جبير قلا :

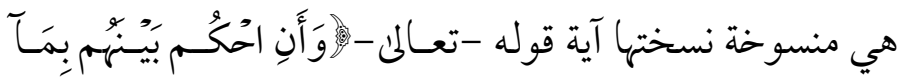

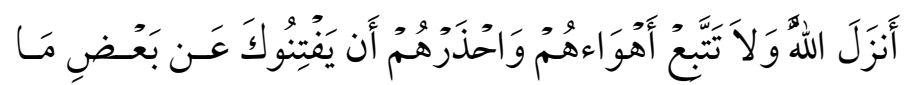

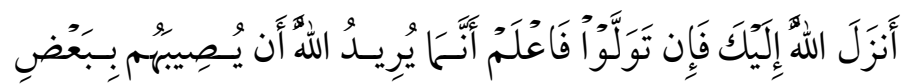

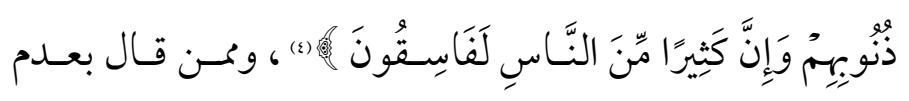

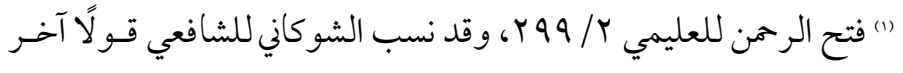

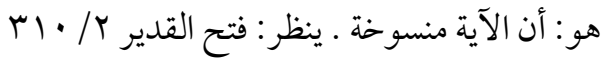

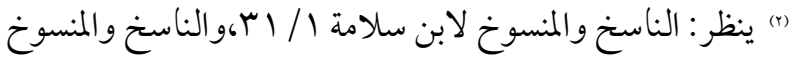

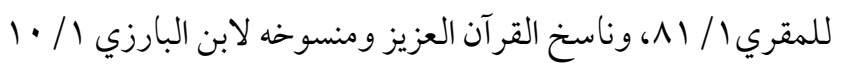

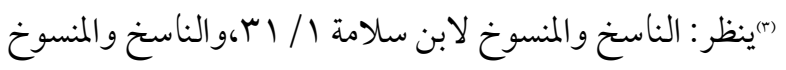

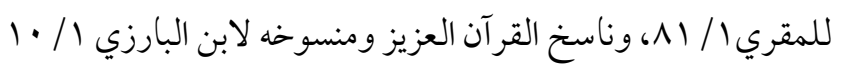

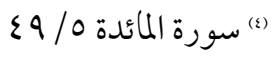


وجود نسخ في الآية من المفسرين الطاهر بن عاشور في التحرير

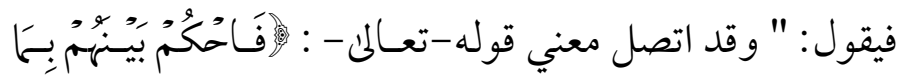

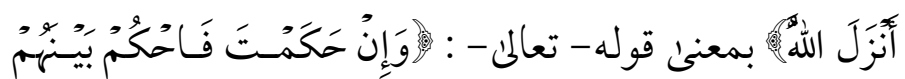

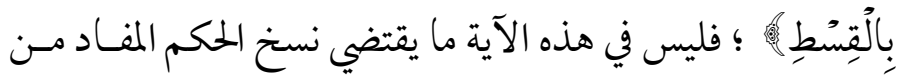

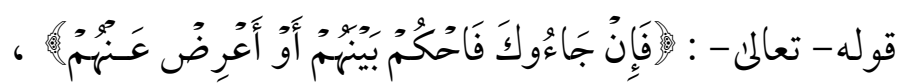

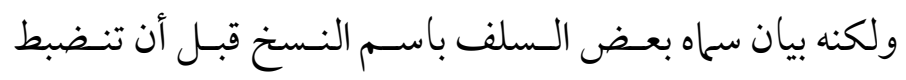
حدود الأسماء الاصطلاحية"). وبعد عرض هذه الأقوال: أري أن الر أي الأولي بالقبول القأتسل

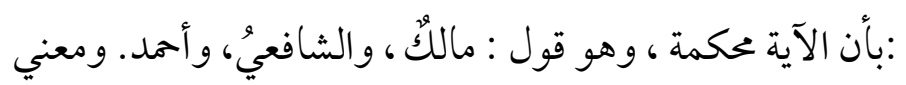

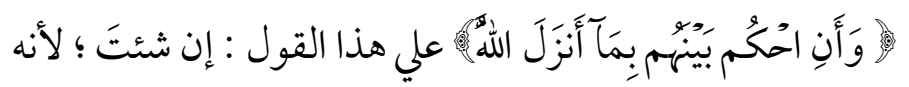

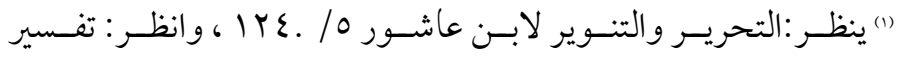

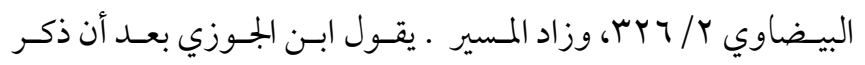

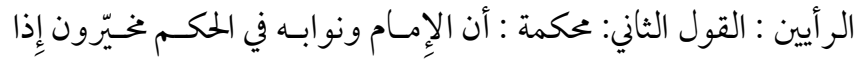

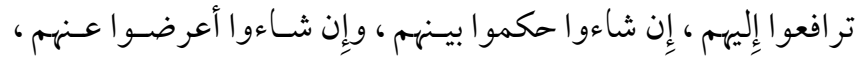

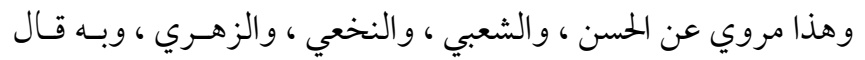

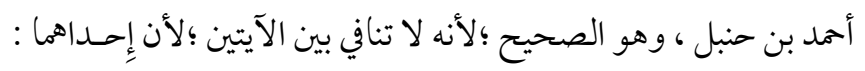

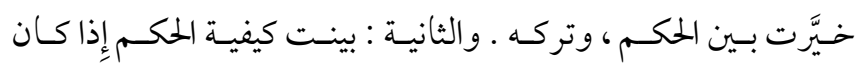
$r / r / r$ 
قد تقدم لفظ التخيير له ، فآخر الكلام حذف منه التخيير لدلالة

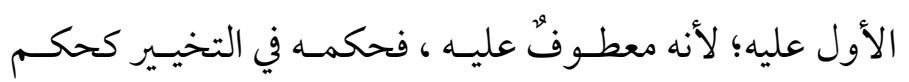

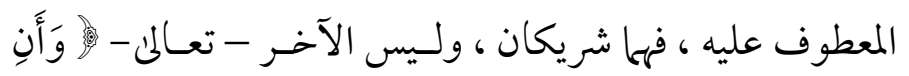

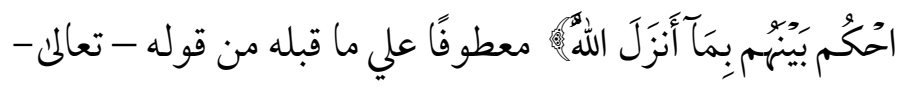

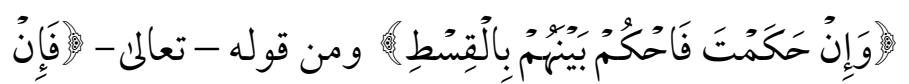

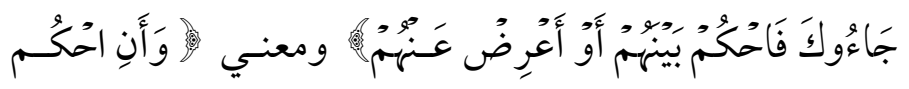

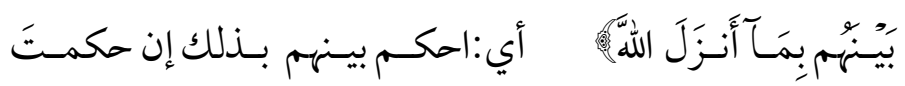

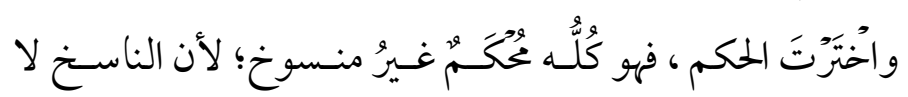

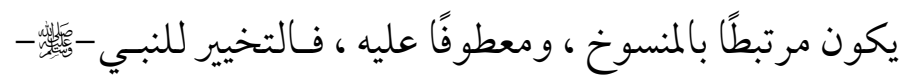

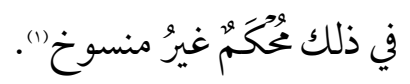

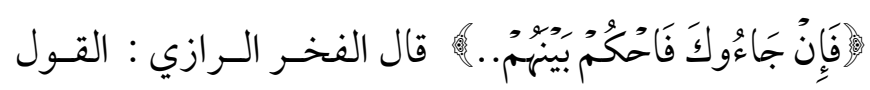

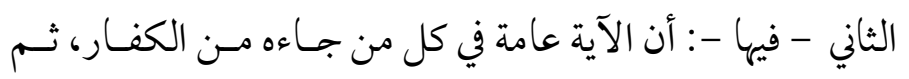

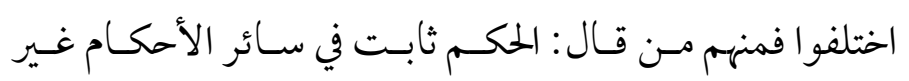
منسوخ ، وهو قول النخعي والشعبي وقتادة ، ومنهم من قال :

"1) ينظر : الإيضاح لناسخ القرآن ومنسوخه لمكي صـrY-rVY 


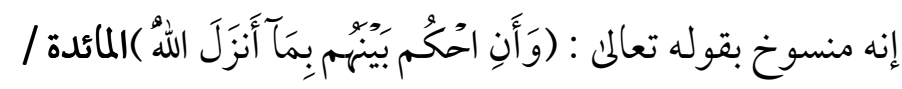

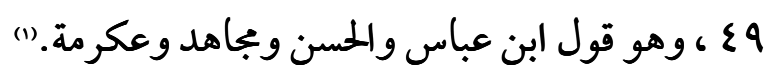

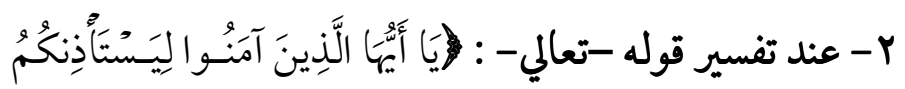

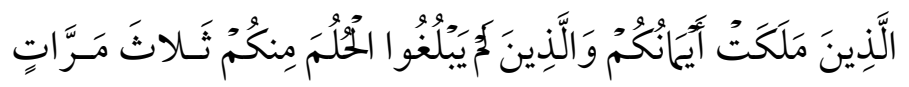

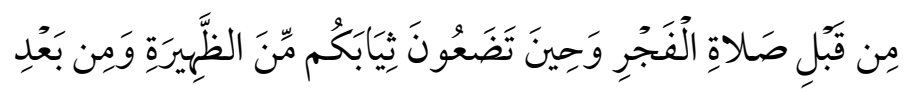

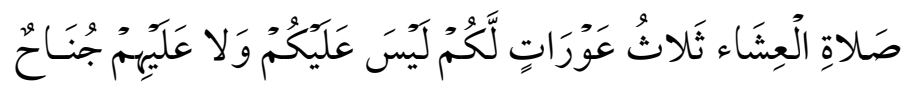

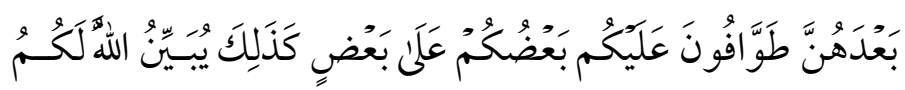

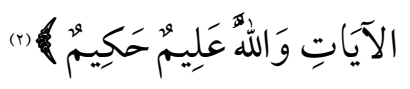

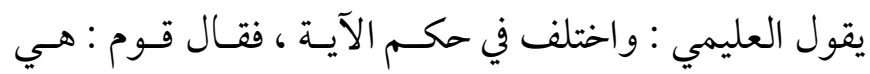

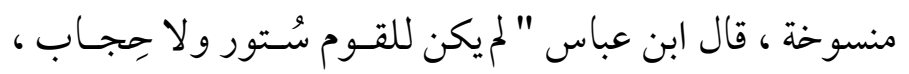
وكان المدم ، والو لائد يدخلون ، فربا يرون منهم ما لا يحبـون ،

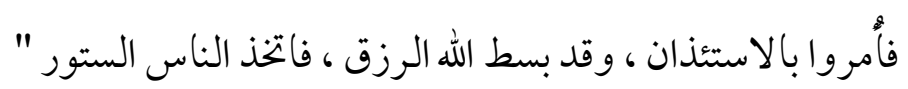

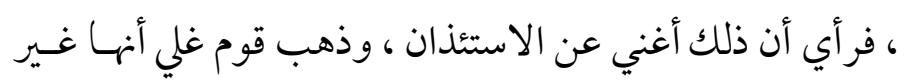

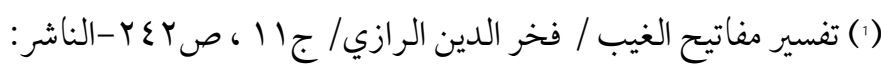

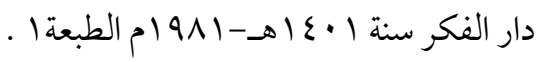

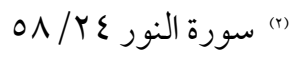




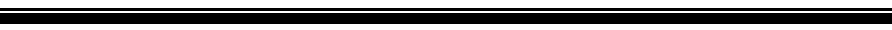

منسوخة ، قال سعيد بن جبير : " إن ناسَّا يقولـون : نُسِسخت ، والله مانُسِتت ، ولكنها ما تهاون الناس بها " "(1). هذا ما ذكره العليمي ـ وكثر كلام المفسرين بين نسخها ، وبقائها

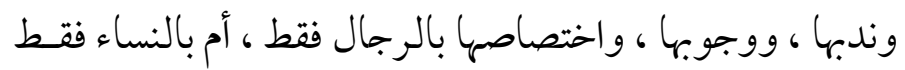
كذلك بين الصحابة ، والتابعين في آراء نسبت إليهم . فممن قال

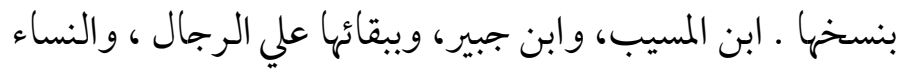
: كثير من أهل العلم منهم : القاسم، وجابر بن زيد ، والشعبي. وبندبها ـ أبو قلابة " همن قال هي في الرجال فقط : عبد الله بن

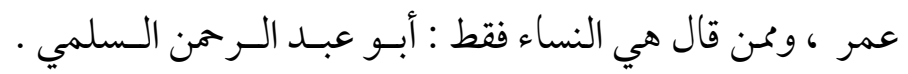

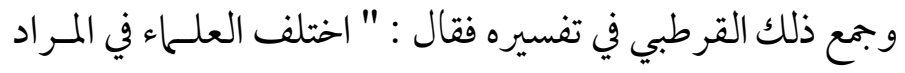

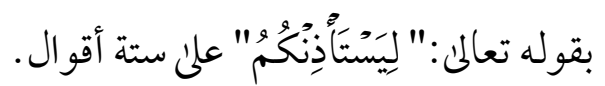
الأول- أنها منسوخة، قاله ابن المسيب وابن جبير.

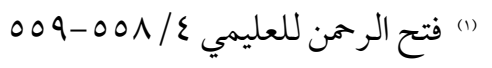

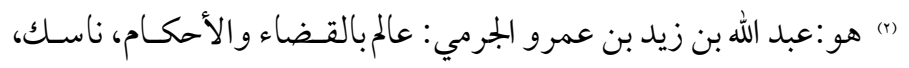

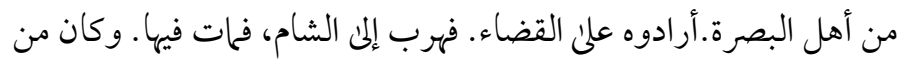
رجال الحديث الثقات، تـ ع • اهـــ ينظـ :صفة الصفوة لابسن الجـوزي

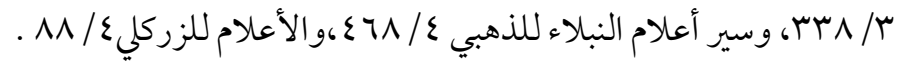




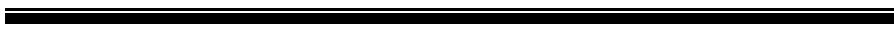

الثاني - أنها ندب غير واجبة، قاله أبو قلابة، قال: إنـا أمـروا هذذا نظرًا لهم. الثالث- عني بها النساء، قاله أبو عبد الرممن السلمي.

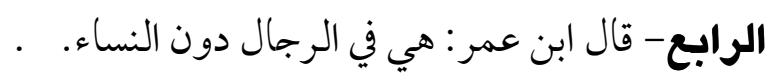

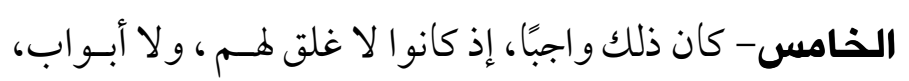
ولو عاد المال لعاد الوجوب، حكاه المهدوي عن ابن عباس.

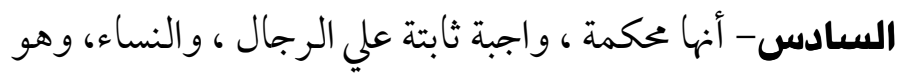

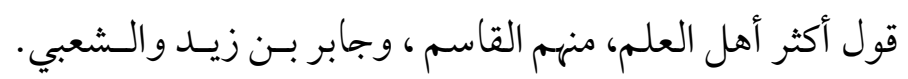

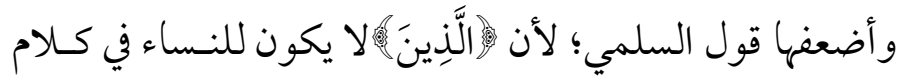

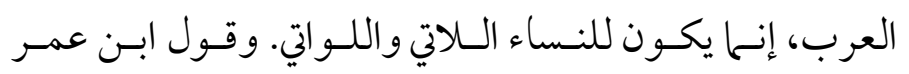

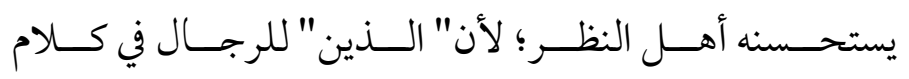

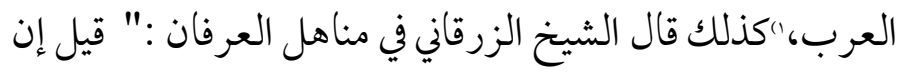

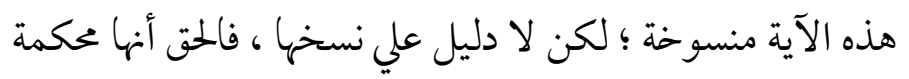

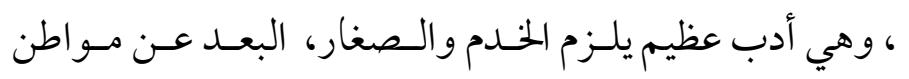

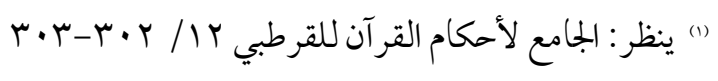


كثف العورات ماية للأعراض من الانتهاك، وحفظًا للأنظـار

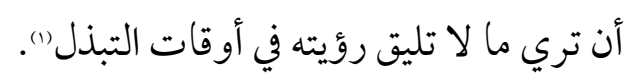

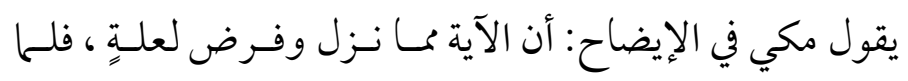
زالت تلك العلة زال الحكمم، وبقي اللفظ متلوًً (ه). . والراجح أن الآية محكمة وليست منسوخة؛ لقوة كلام أصحاب لقاب

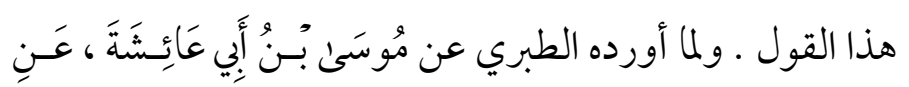

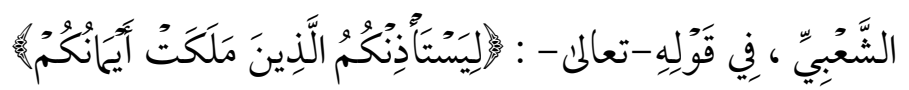

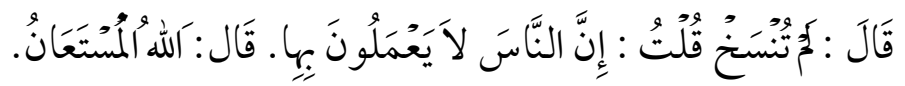

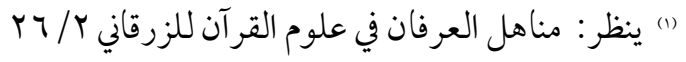

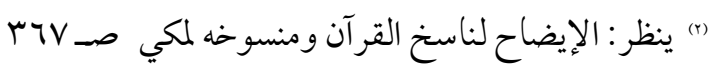

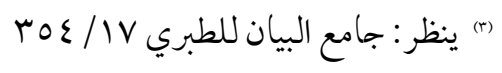




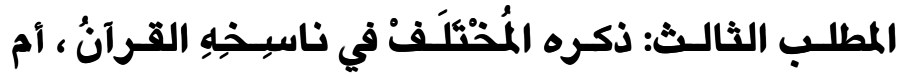

السنة (1).

(1) اختلف أهل العلم في جواز نسخ القرآن بالسنة، فأجازه أبو الفرج وغيره

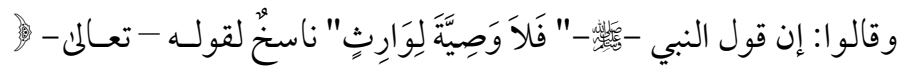

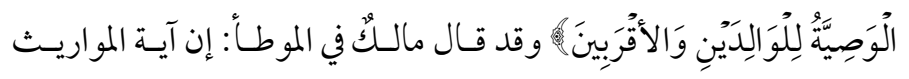

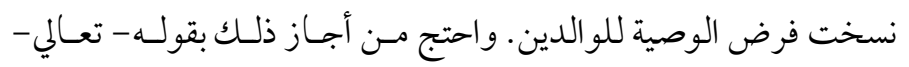

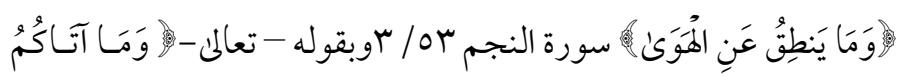

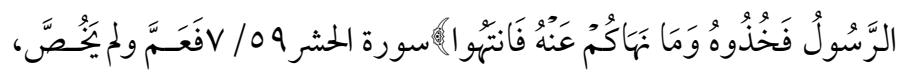

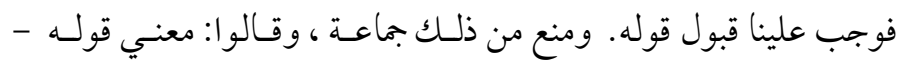

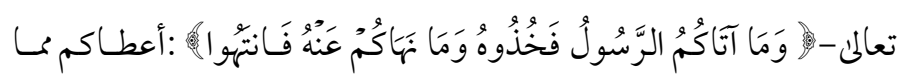

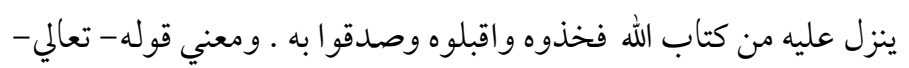

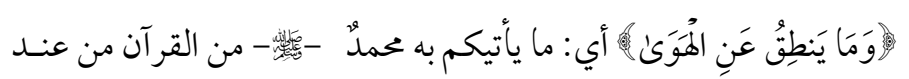

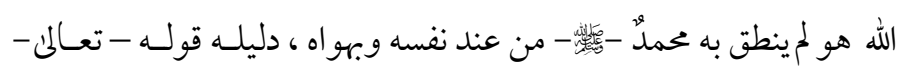

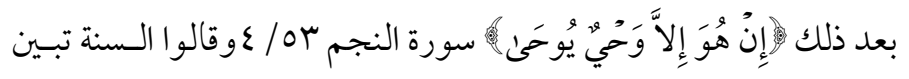

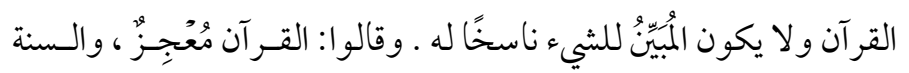

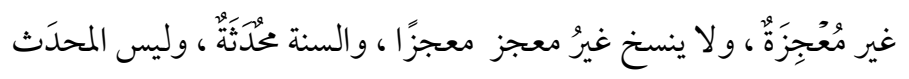

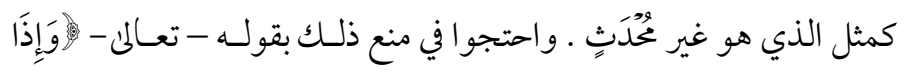

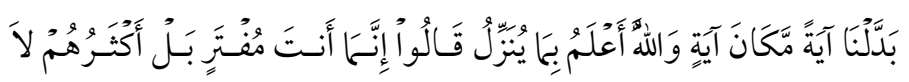

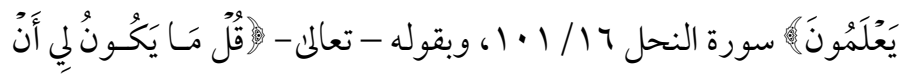

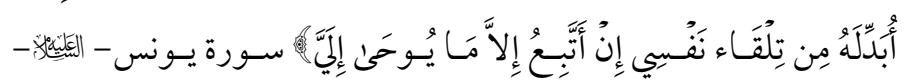




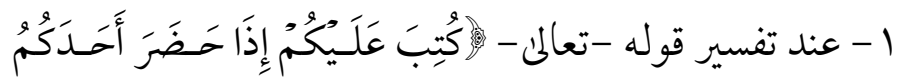

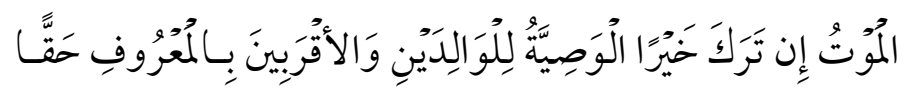

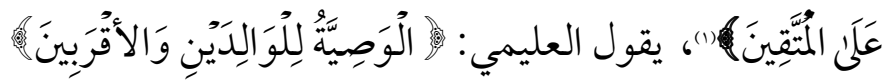

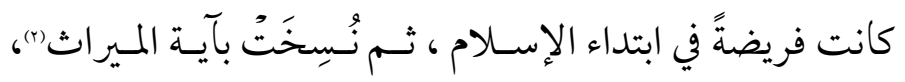

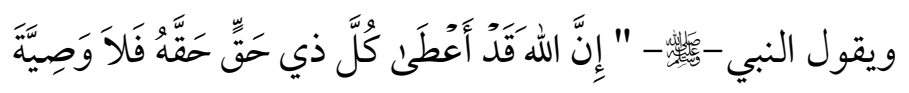

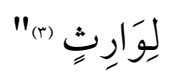

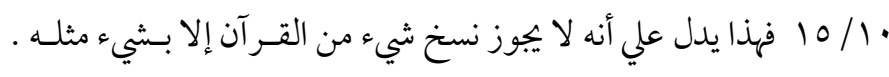

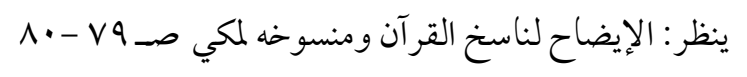

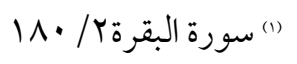

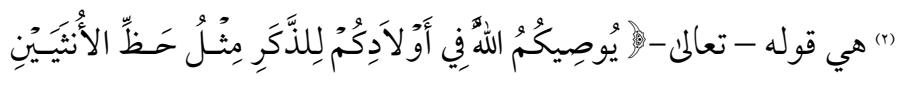

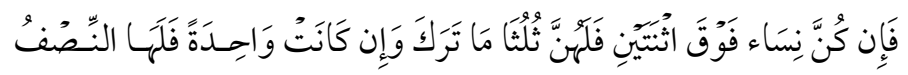

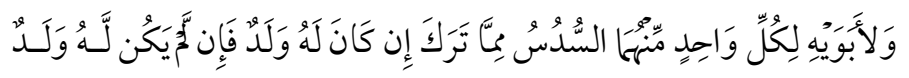

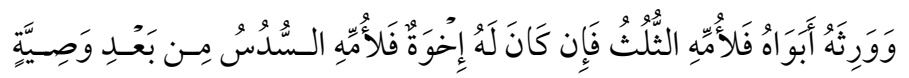

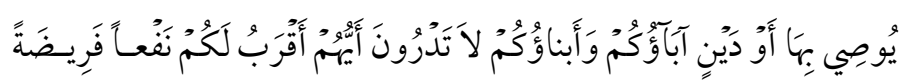

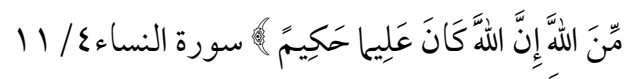

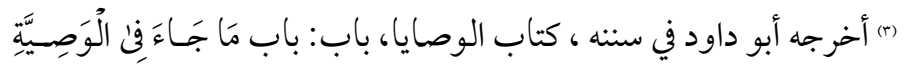

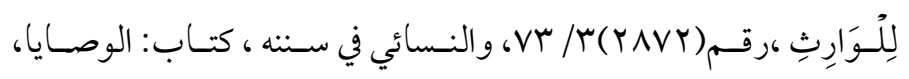

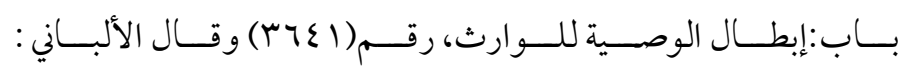
r\&V/Trive 


$$
\begin{aligned}
& \text { و أجد العليمي في هذه الآية ذكر الناسخ للآيـة مـن القــرآن ، }
\end{aligned}
$$

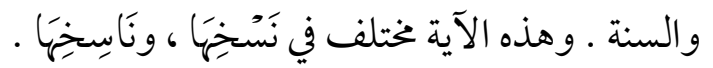

$$
\begin{aligned}
& \text { يقول ابن الجوزي في نواسخ القرآن : اختلف المفسرون في هـــهـ } \\
& \text { الوصية، هل كانت واجبة أم لا؟ علي قولين: }
\end{aligned}
$$

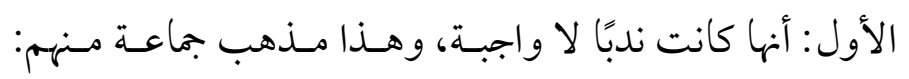

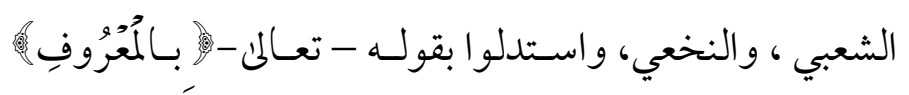

$$
\begin{aligned}
& \text { قالوا: المعروف لا يقتضي الإيجاب وبقوله - تعالن - عَلَّن المُتَّقينَ }
\end{aligned}
$$

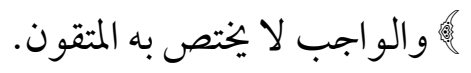

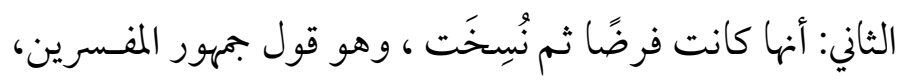

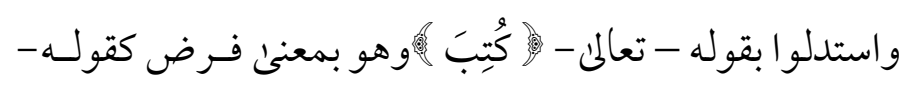

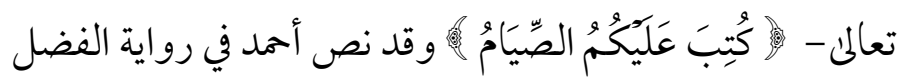

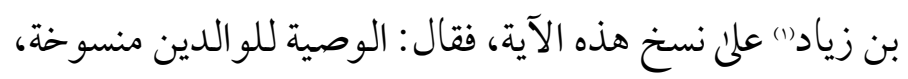

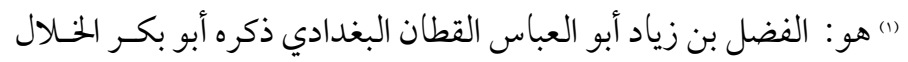

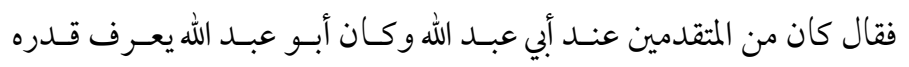

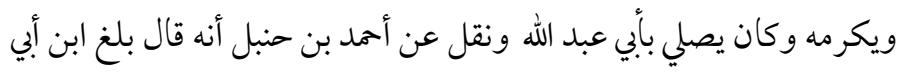

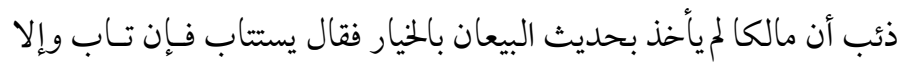
ضربت عنقه ومالك لم يرد ، وقال الفضل: سمعت أممد بـن حنبل مـرارًا يقول الإيهان قول وعمل ، يزيد وينقص ، وقال: أكذب النساس السؤ ال ، 


$$
\begin{aligned}
& \text { وأجــاب أربــاب هـــا القـــل ، أهــل القــول الأول: فقــالوا }
\end{aligned}
$$

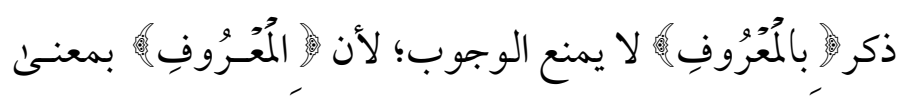

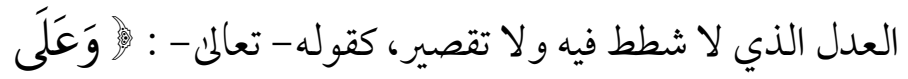

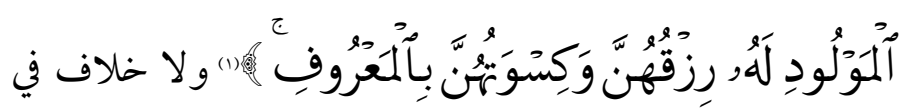

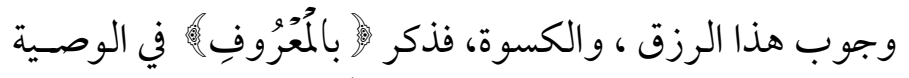

$$
\begin{aligned}
& \text { لا يمنع وجو.بها بل يؤكده، وكذلك تخصيص الأمر بالمتقين دليـل } \\
& \text { علي تو كيده ؛ لأنها إذا وجبت علئ المتقين كان وجُوبهُ علي غيرهم }
\end{aligned}
$$

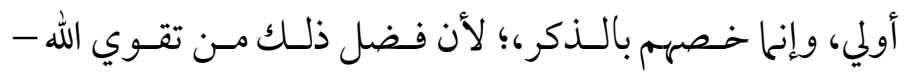

$$
\begin{aligned}
& \text { تعالي - : والتقوى لجميع الخلق. } \\
& \text { ثم اختلـف القـائلون، بإيهـاب الوصسية ونستخها بعـد ذلـك في }
\end{aligned}
$$

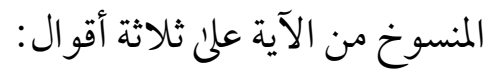

$$
\begin{aligned}
& \text { القول الأول: أن جميع ما في الآية من إيجاب الوصية منسوخ قاله } \\
& \text { ابن عباس -رضي الله عنها|- - قال ابن الجوزي بـسنده عـن ابـن }
\end{aligned}
$$

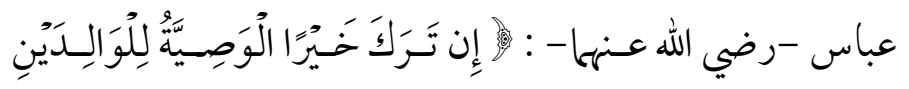

$$
\begin{aligned}
& \text { والقصاص .ينظر : المقصد الأرشد في ذكر أصحاب الإمـام أمـــل لبرهـان }
\end{aligned}
$$

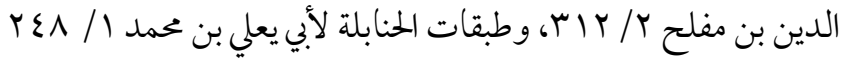

$$
\begin{aligned}
& \text { (1) سورة البقرة T/ كبr. }
\end{aligned}
$$




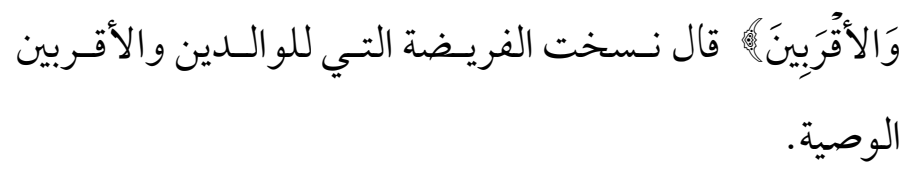

وقال عكرمة عن ابن عباس في هذه الآية، كانت الوصية كـلك

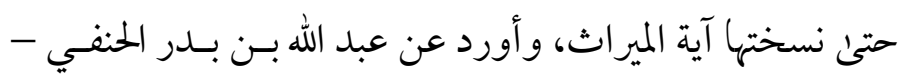

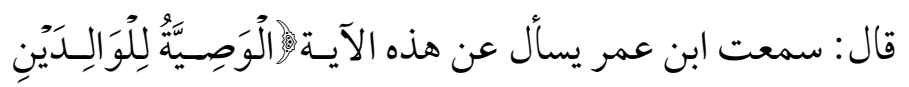

وَالأقرَبِينَ هُ قال نسختها آية المواريث.

القول الثاني: إنه نسخ منها الوصية للو الدين.

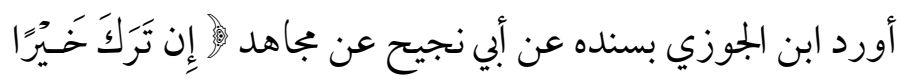

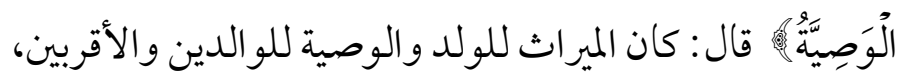

ثم نسخ منه الو الدين. وأورد عن مغيرة عن إبر اهيم قال: كانت

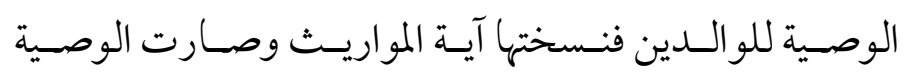

لأأقربين.

القول الثالث: إن الذي نُسِخ من الآية: الوصية لمن يـرث ، ولم

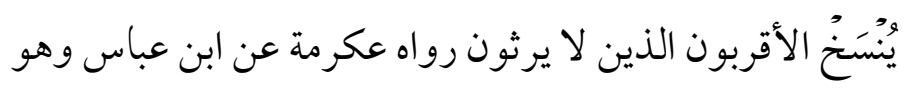
قول الحسن والضحاك وأبئ العالية.

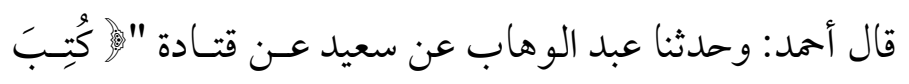

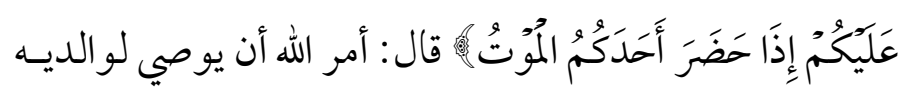

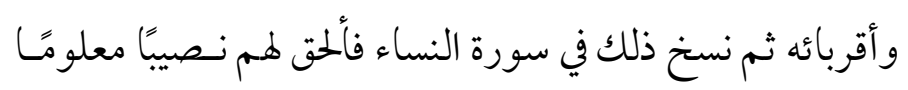




$$
\begin{aligned}
& \text { وألحق لكل ذي ميراث نصيبه منه ولـيس لهـم وصسية فصارت } \\
& \text { الوصية لمن لا يرث من قريب ، أو بعيد. } \\
& \text { و أورد عن شرحبيل بن مسلم، قال: سـمعت أبـا أمامـة البـاهلي }
\end{aligned}
$$

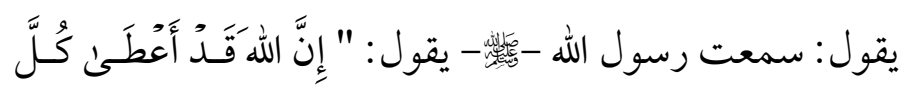

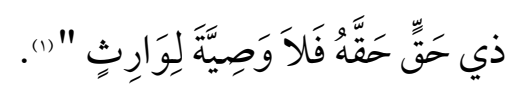

$$
\begin{aligned}
& \text { والذي يظهر في هذه الآية: أن الله -تعالئ - كان قد فـرض علينـا }
\end{aligned}
$$

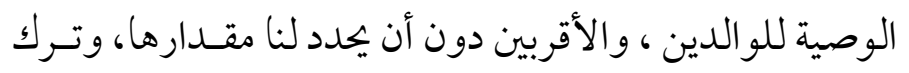

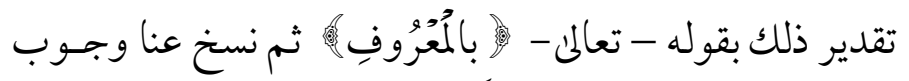

$$
\begin{aligned}
& \text { الوصية وجعل ذلك لنفسه بجا فـرض مـن الفــائض والمواريـث }
\end{aligned}
$$

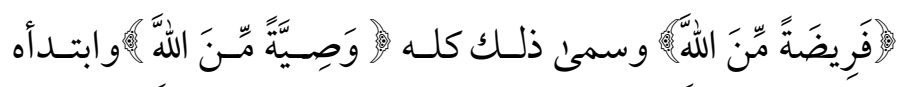

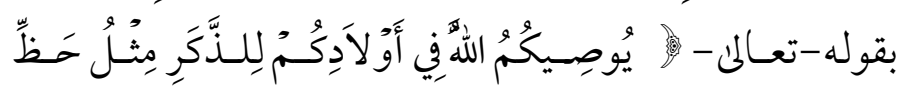

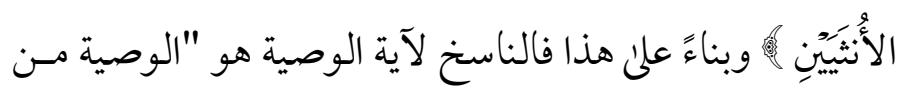

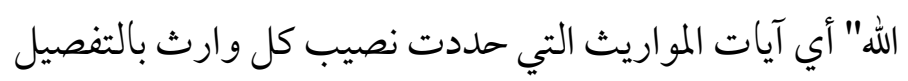

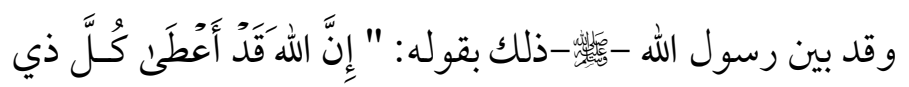

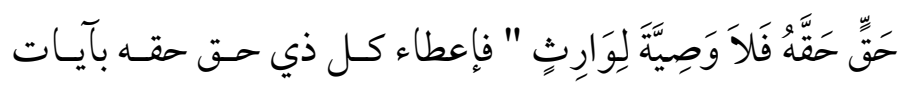

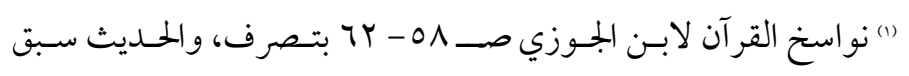

$$
\begin{aligned}
& \text { تخريه. }
\end{aligned}
$$




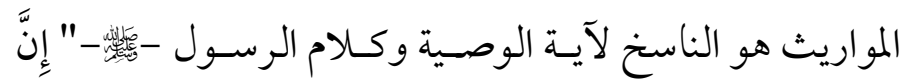

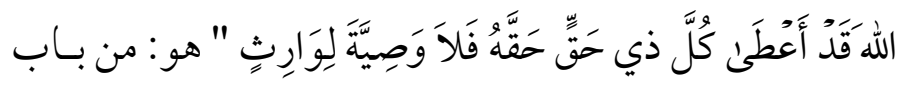

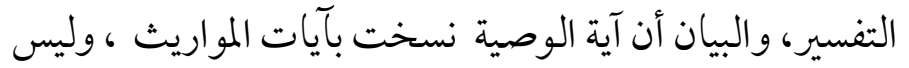

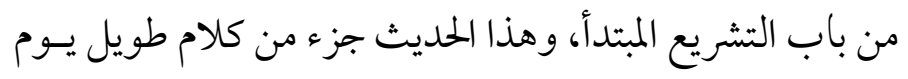

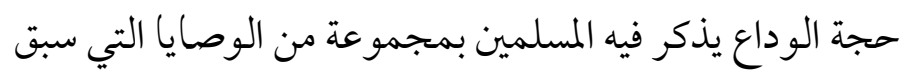
أن عرفوها وذلك من باب العناية والتأكيد.

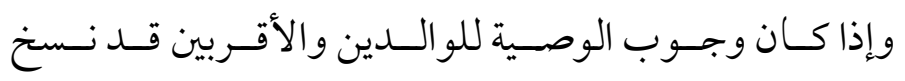

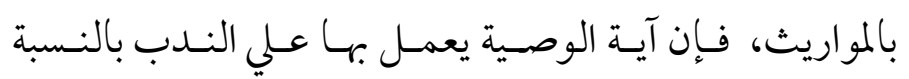
للو الدين غير الوارثين والأقرباء من غير الورثة، ويدل علي أنها

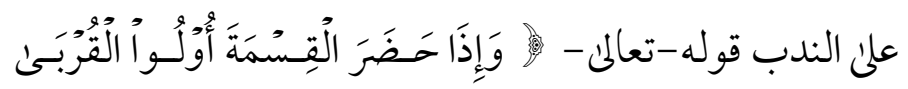

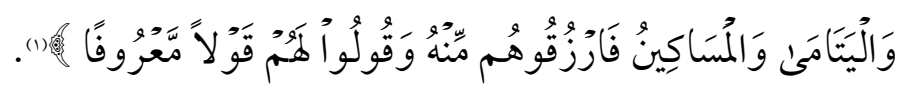

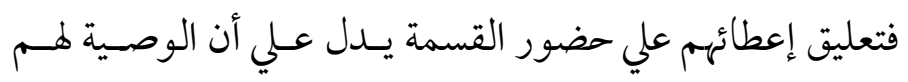
ليست واجبة.

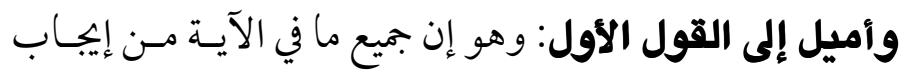

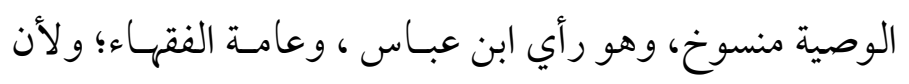

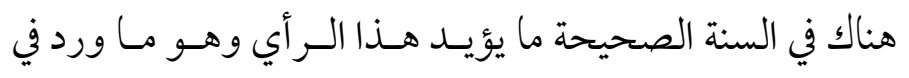

$$
\text { 1) ع (1) }
$$


صحيح البخاري عن ابن عباس - رضي الله عنها- قال: كَانَ

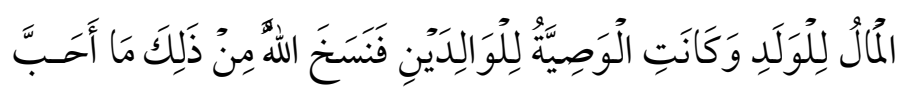

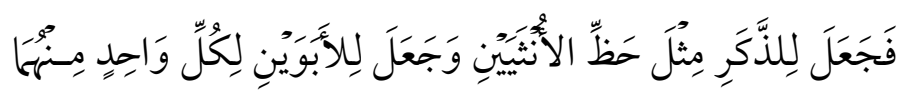

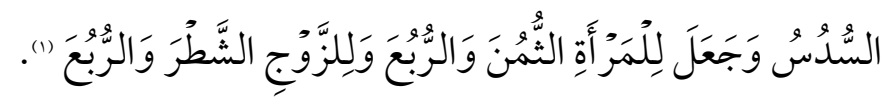

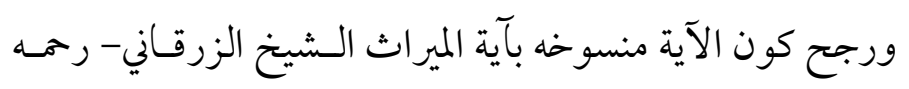

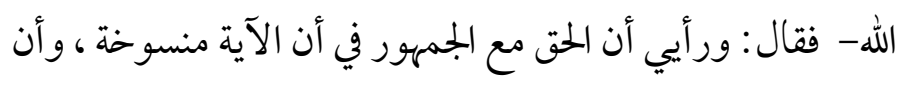

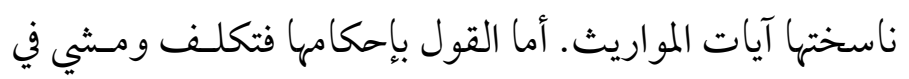
غير سبيل؛ لأن الو الدين - وقد جاء ذكرهما في الآيـة لا يحرمـان

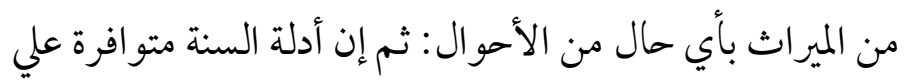

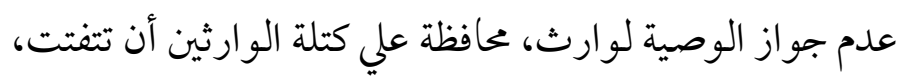

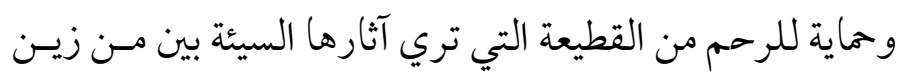

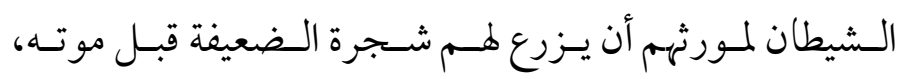

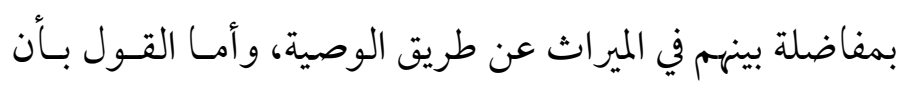

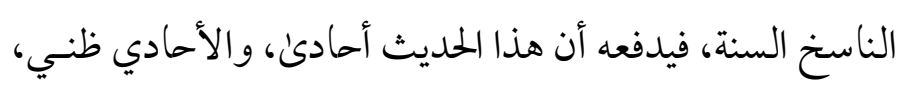

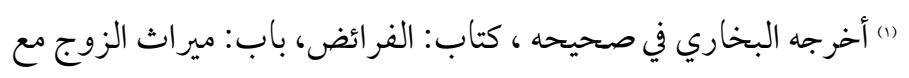

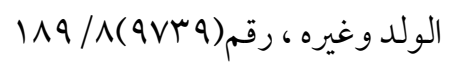




$$
\begin{aligned}
& \text { و الظني لا يقون علي نسخ القطعي وهو الآية، وأما القـول بـأن } \\
& \text { الناسخ هو الإجماع فيدفعه عدم جواز نسخ الإجماع والنسخ بهاه ل(1). } \\
& \text { وورد في تفسير الحسن البـصري في الآيـة : قـال : (للوالــين) } \\
& \text { منسوخة والوصية للقرابة حتى وإن كانوا أغنياء.(") فدل هذا علي } \\
& \text { أن الوصية منسوخة بآيات المواريث وهو الـراجح عنــ جمهـور } \\
& \text { المفسرين . }
\end{aligned}
$$

$$
\begin{aligned}
& \text { (1) مناهل العرفان في علوم القرآن للزر قاني / / TVV- rVT - بتصرف. }
\end{aligned}
$$

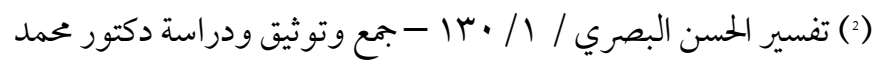

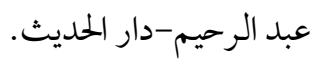


المطاب الرابع: إكثاره هن ذكر المنسوغ بآية السيف.

يذكر العليمي آيات كثيرة منسو خة بآيات القتال أو السيف .

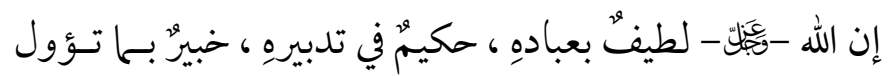

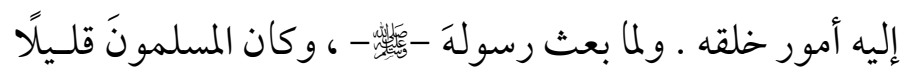

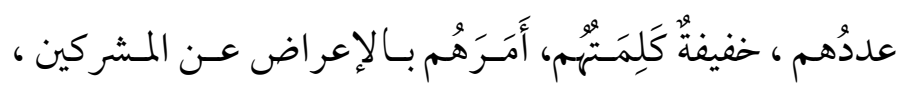

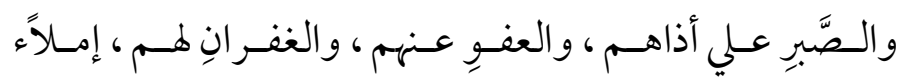

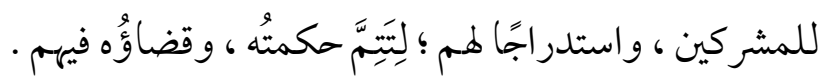

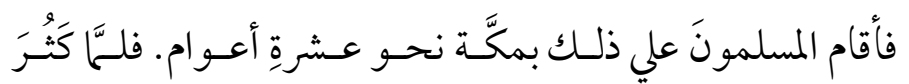

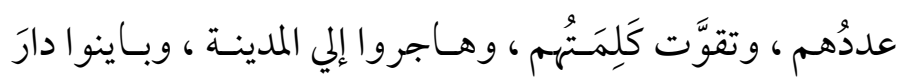

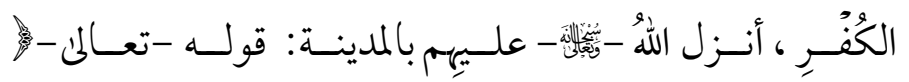

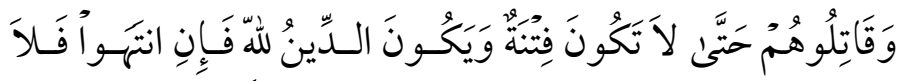

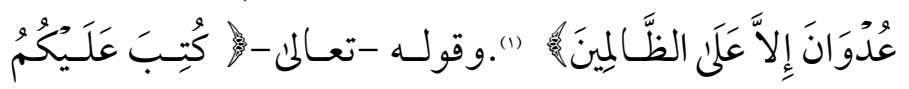

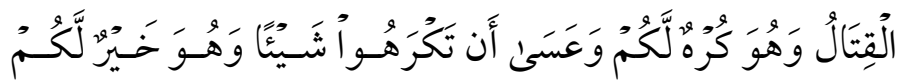

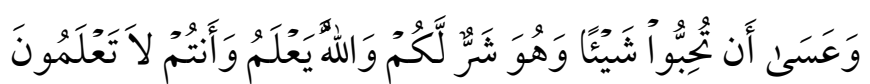

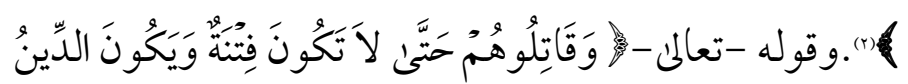

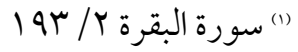

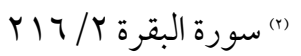




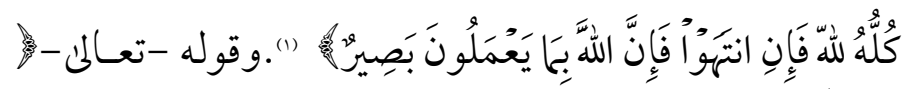

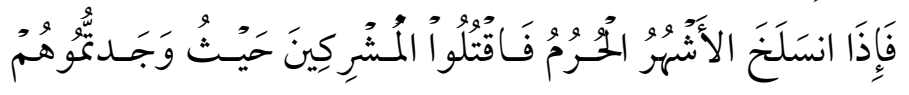

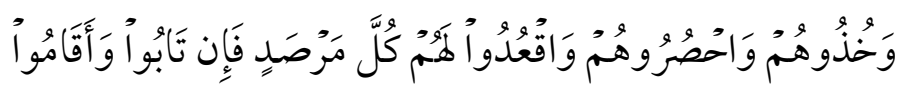

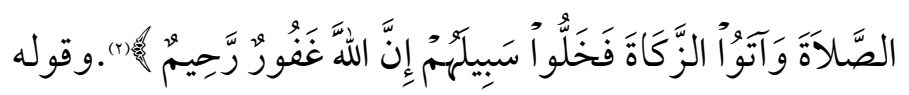
-

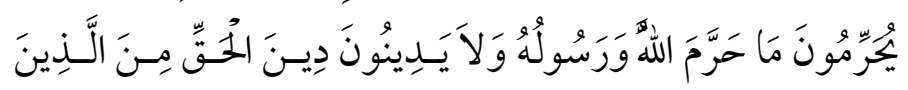

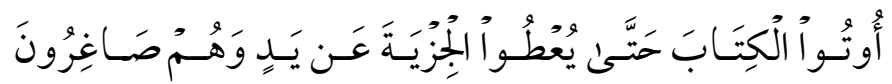

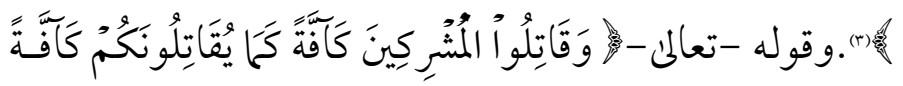

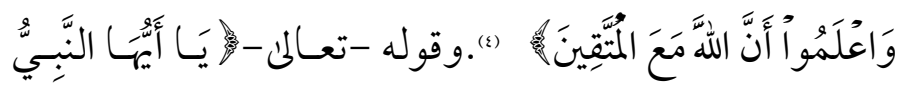

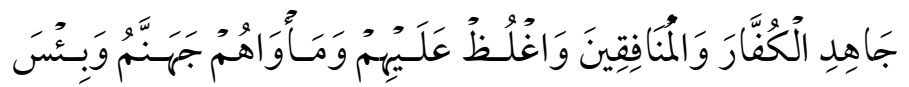

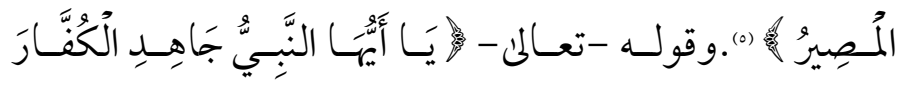

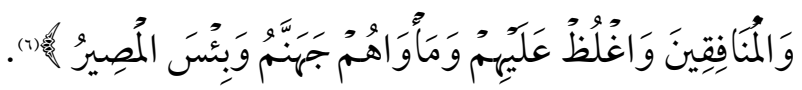

$$
\begin{aligned}
& \text { (1) سورة الأنفال ه/ } \\
& \text { (1) سورة التوبة } 9 \text { / }
\end{aligned}
$$

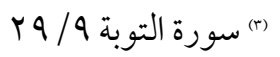

$$
\begin{aligned}
& \text { (2) سورة التوبة 9/ דr } 9 \\
& \text { VY / سورة التوبة } 9 \text { (0) } \\
& \text { (1) سورة التحريم } 977
\end{aligned}
$$




$$
\begin{aligned}
& \text { والعليمي من الذين أكثروا من ذكر المنسوخ بآيات القتال ، أو } \\
& \text { السيف. }
\end{aligned}
$$

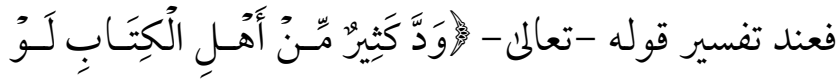

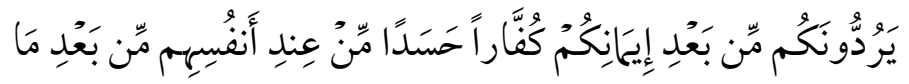

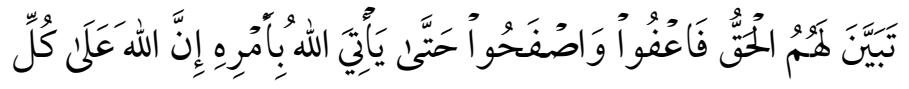

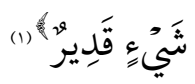

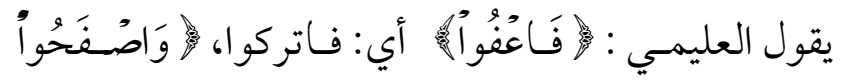

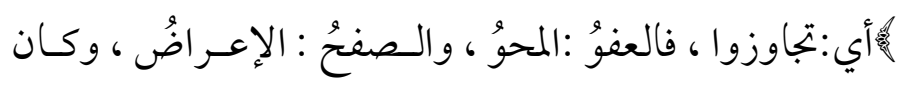

$$
\begin{aligned}
& \text { هذا قبلَ آية القتال"). } \\
& \text { هذه الآية ختلف فيها بين النسخ ، وبقائها عحكمة . }
\end{aligned}
$$

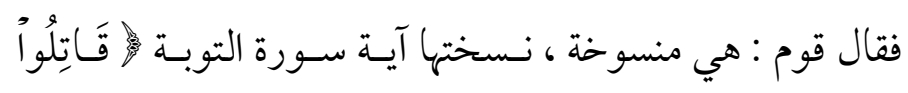

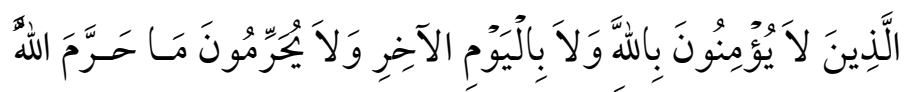

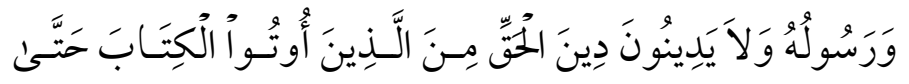

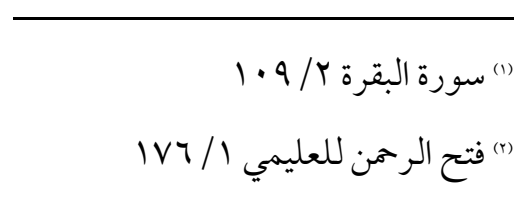




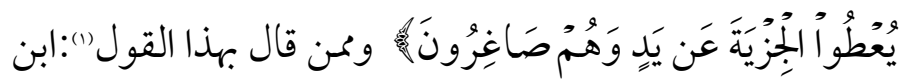

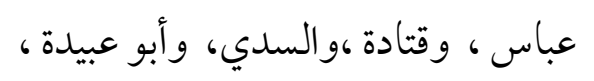

وقال قوم : هي محكمة ، وممن قال بهذا : ابن الجوزي ، فيقول :

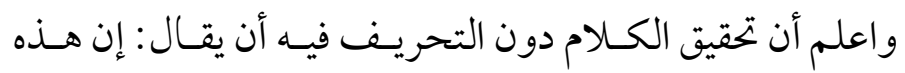

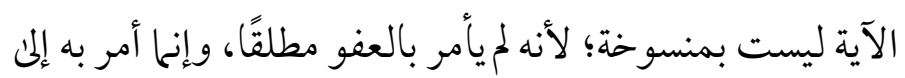

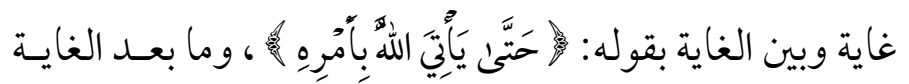

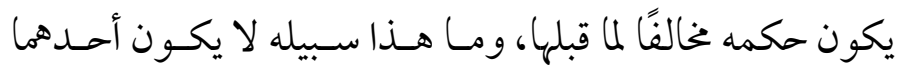
ناسخًا للآخر، بل يكون الأول قد انتضت مدته بغايته والآخر

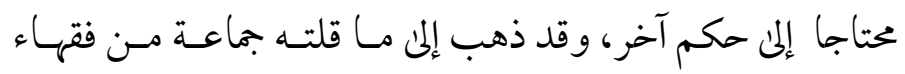
المفسرين وهو الصحيح ، وهذا إذا قلنا: إن المراد بـالعفو عن فئن قتالهم "وقد قال الحسن: هذا فيا بينكم وبينهم دون ترك حق الله تعالئ حتئ يأتي الله بالقيامة.

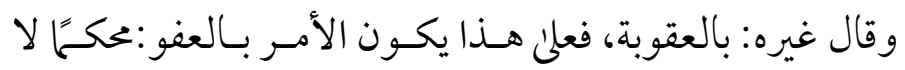

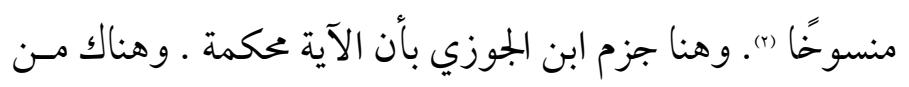

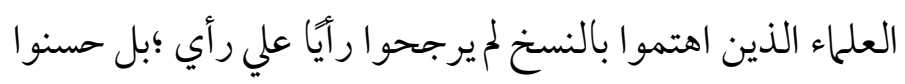

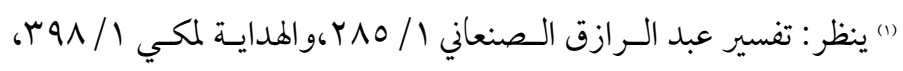

$$
\begin{aligned}
& \text { والجامع للقرطبي / • V. }
\end{aligned}
$$

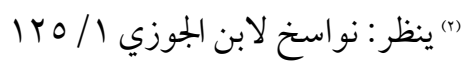


القولين كمكي ـ فيقول في الإيضاح: هذه الآية -عند السدي-

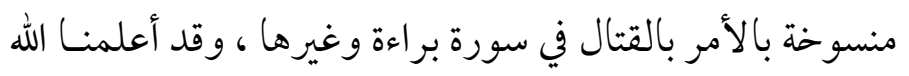

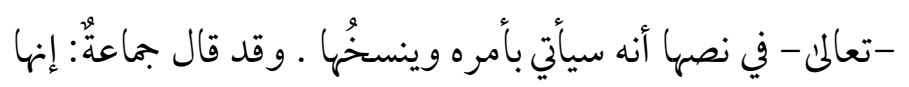

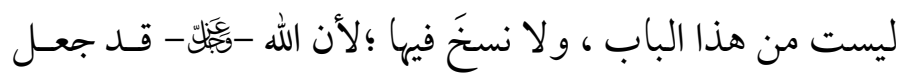

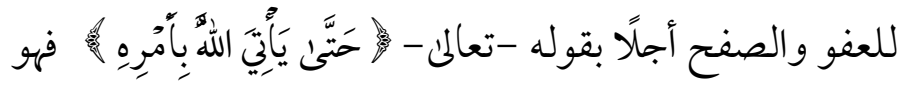

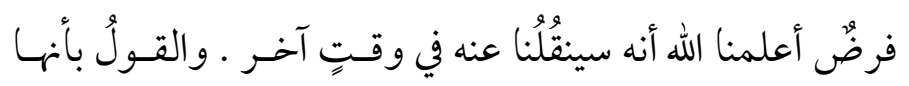

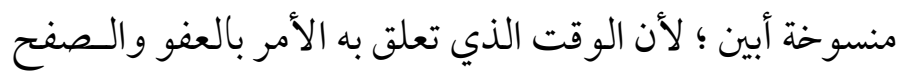
غير معلوم حده ، وأمده ، ولو حد الوقت وبينه فقال إلي وقدبِ

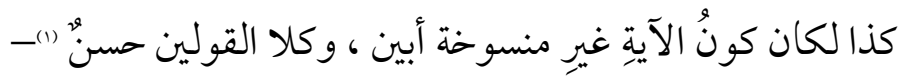

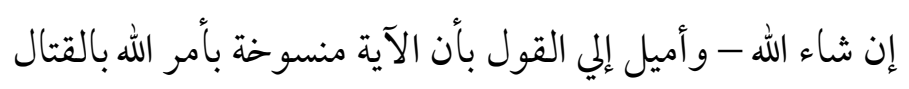

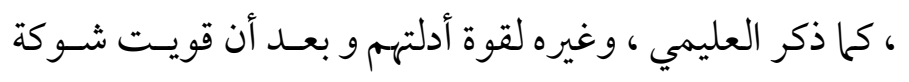

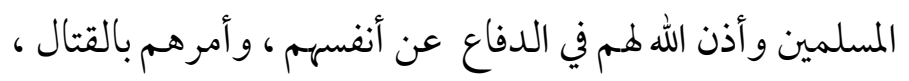

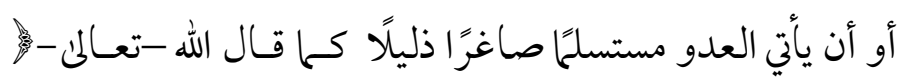

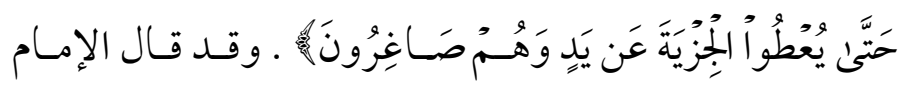

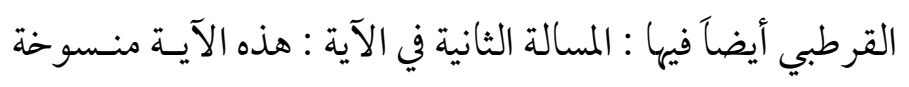

(1) ينظر : الإيضاح لمكي صـ بr| 


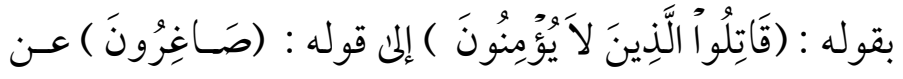

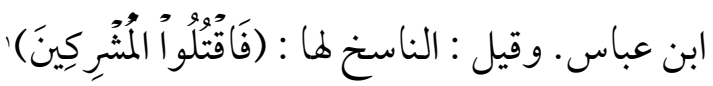

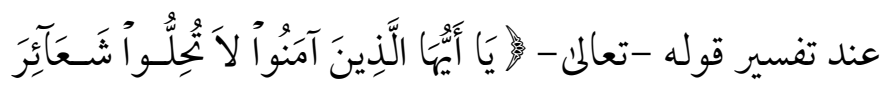

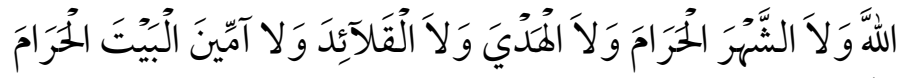

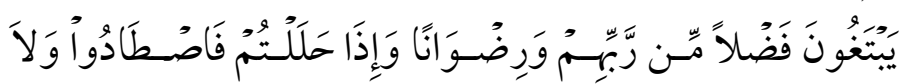

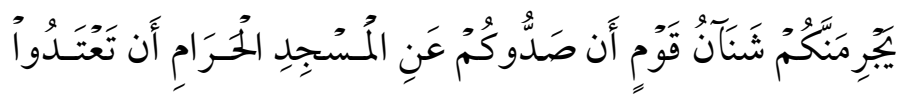

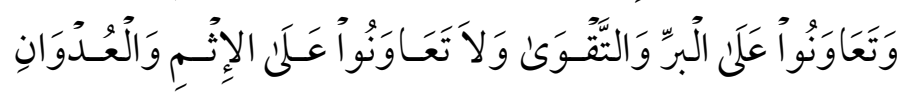

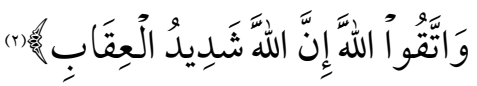

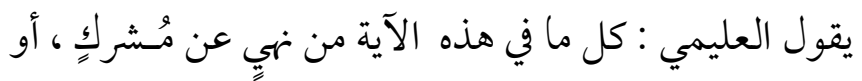

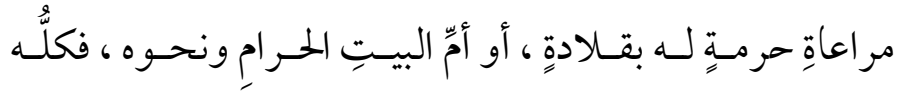

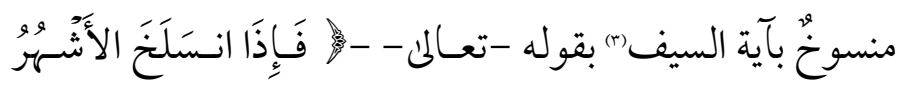

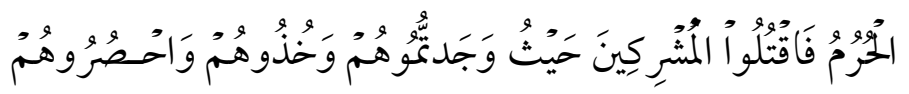

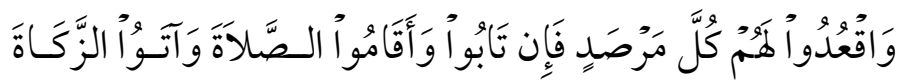

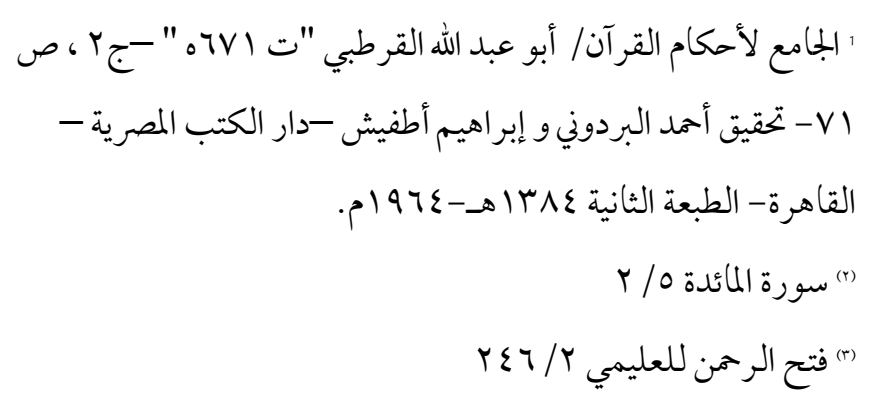




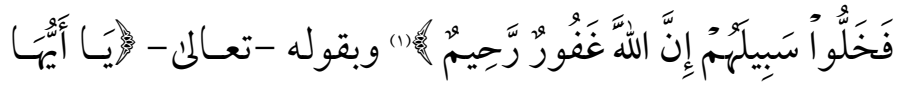

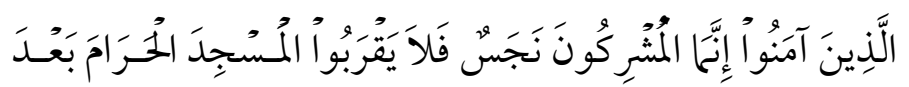

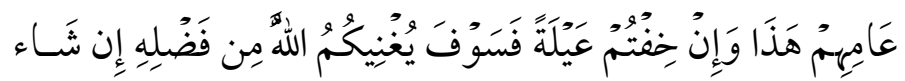

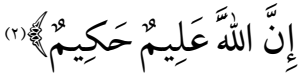

$$
\begin{aligned}
& \text { كما سبق من كلام العليمي في هذه الآية فإنه قال بنسخ ما فيها }
\end{aligned}
$$

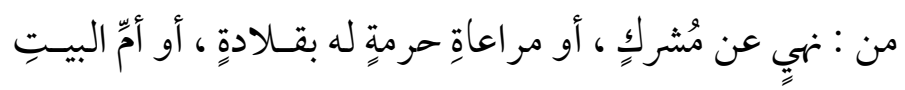

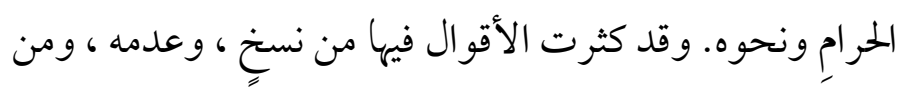

$$
\begin{aligned}
& \text { نسخِ بعضها دون البعض. }
\end{aligned}
$$$$
\text { فمن الذين قالوا بنسخ بعضها ، وإحكام البعض الآخر . بجاهد ، }
$$

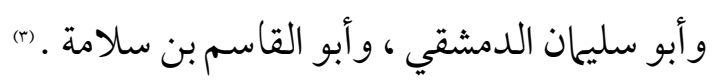$$
\text { ومن الذين قالوا بنسخها كاملة :ابـن عباس، وقتادة ، وقتادة }
$$

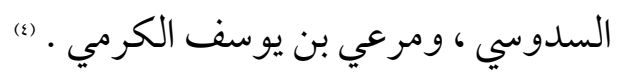

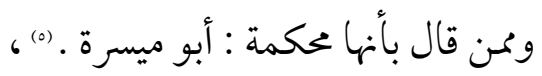

$$
\begin{aligned}
& \text { (1) سورة التوبة } 9 \text { / }
\end{aligned}
$$

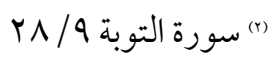

(r) ينظر : الناسخ والمنسوخ لابن سلامة /

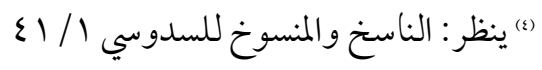
ro ينظر : الناسخ والمنسوخ للنحاس / / 


$$
\text { لكن مكيُ و ابن الجوزيّ فصل الأقوال فيها : }
$$

فيقول ابن الجوزي: اختلف المفسرون في هـذه الآيـة، هـل هـي لهي

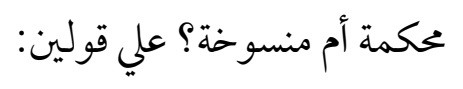

أحدهما: أنها عحكمة، ولايجوز استحلال الشعائر ، ولا الهـدي

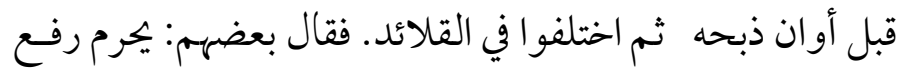
القلادة عن الهدي حتى ينحر.وقال آخرون منهم: كانت الجاهلية

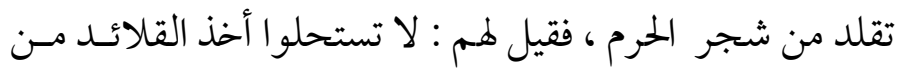
الحرم، لا لا تصدوا القاصدين إلي البيت. والقول الثاني: أنها منسوخة، ثم في المنسوخ منها ثلاثة أقوال:

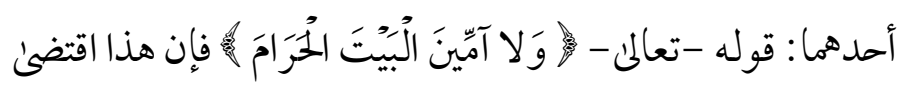

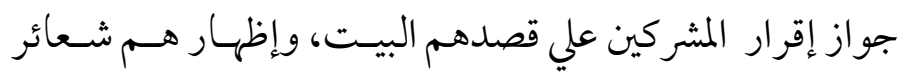

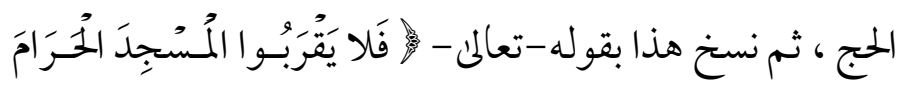

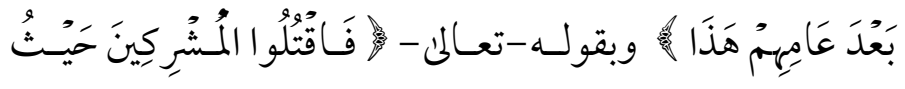

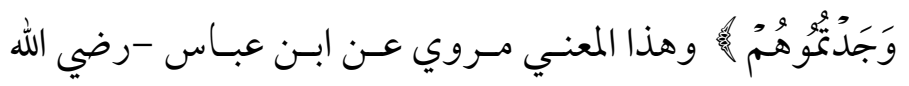

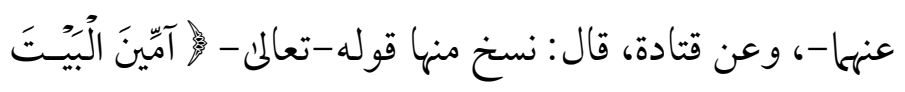

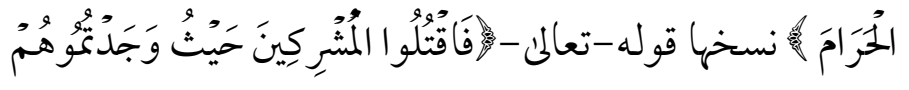

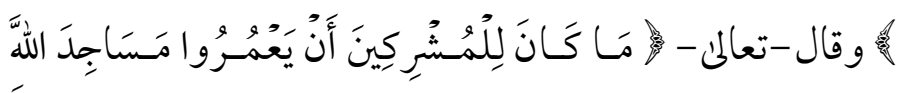




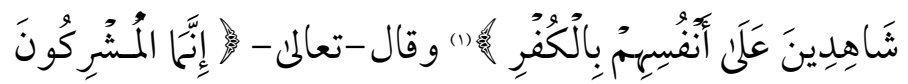

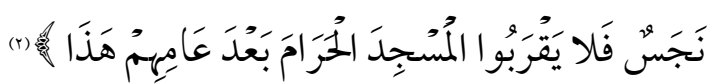

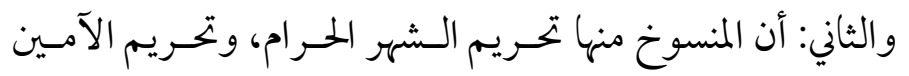

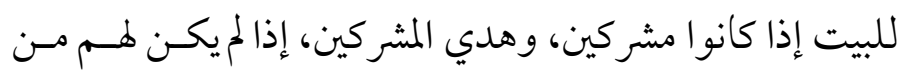

$$
\begin{aligned}
& \text { المسلمين أمان، قاله أبو سليان الدمشقي }
\end{aligned}
$$

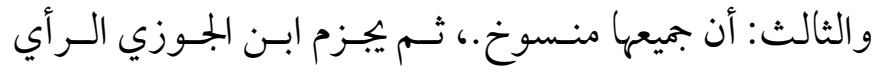

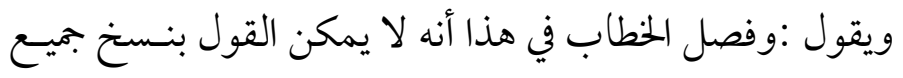

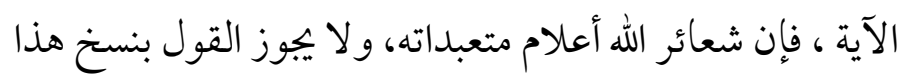

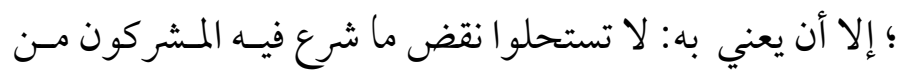

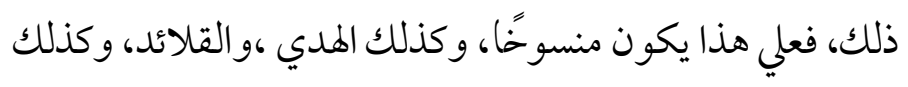

$$
\begin{aligned}
& \text { الآمون للبيت ،فإنه لاييـوز صـدهم، ،إلا أن يكونـوا مـشركين، }
\end{aligned}
$$

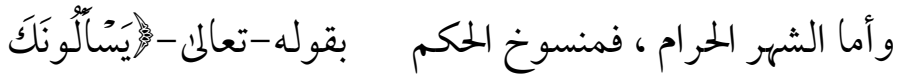

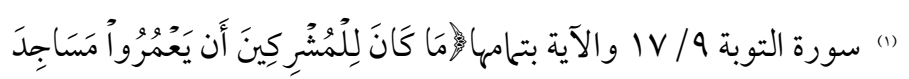

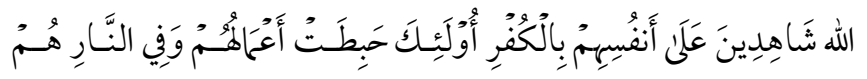

$$
\begin{aligned}
& \text { خَالِددُونَ) }
\end{aligned}
$$

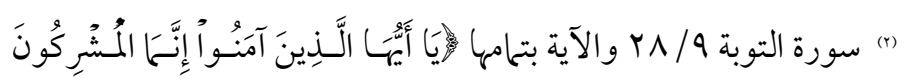

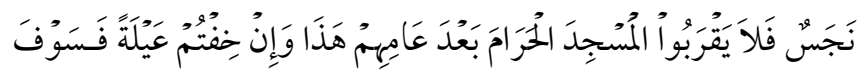

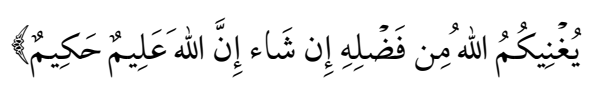




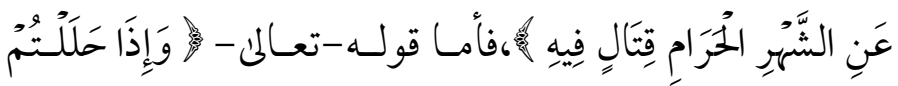

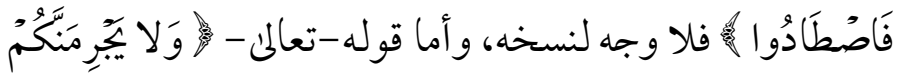

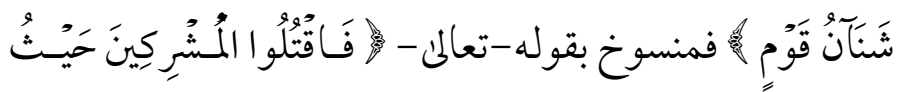

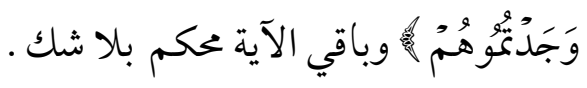

هذا ما ذكره ابن الجوزي من أقوال في الآية ، أما قوله - تعالني-

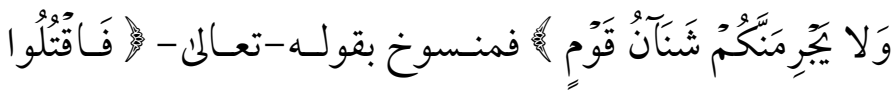

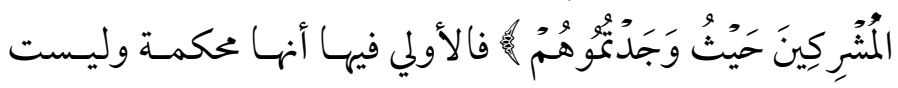

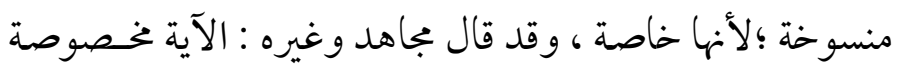

مكمة غير منسوخة ،نزلت في مطالبة المسلمينَ المشركينَ بدخول

الجماهلية ؛أجـل أن صـدوهم عـن المسجد الحــرام عـام الحديبيـة

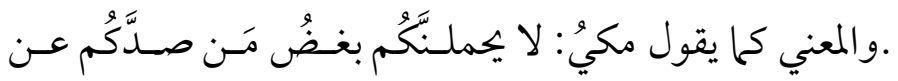

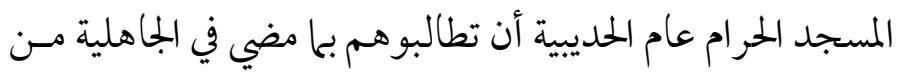

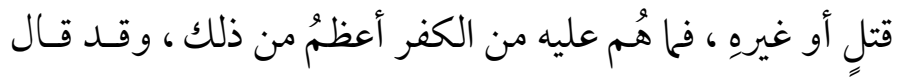

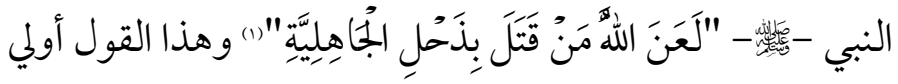

"(1) ورد هذا الحديث بلفظه في تفسير مجاهد / / /99 ك، وجامع البيان للطبري

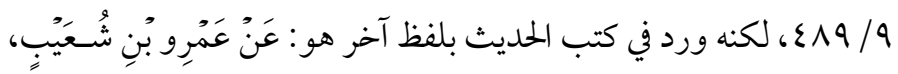

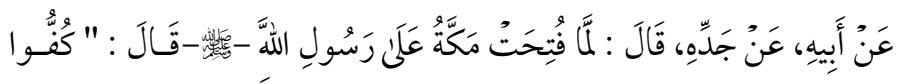

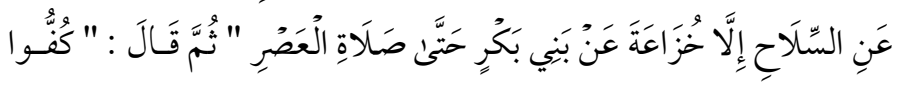

- Tr 
بالآية ، وأحسن "). وذُكِكر قول آخر: أن المأئدة لا منسوخ فيها . لكنه ضعيف ـ والقول المختار أن الآية بعضها منسوخ ، وبعضها مكمم كما سبق.

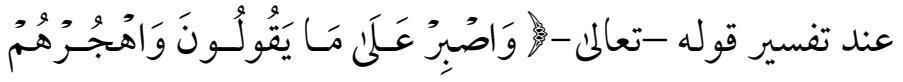
هَجْرَا مجمِيلاً (1)

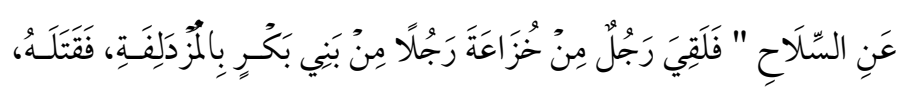

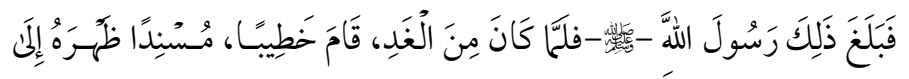

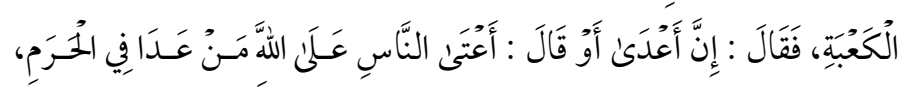

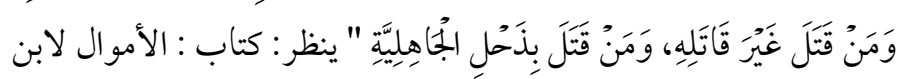

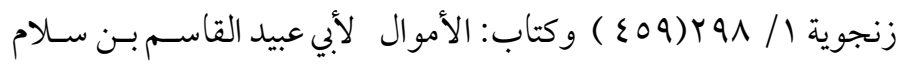

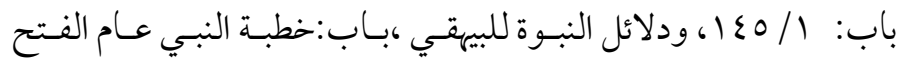

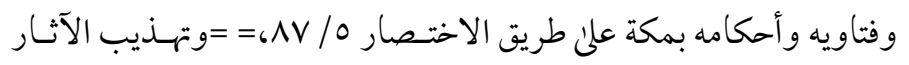

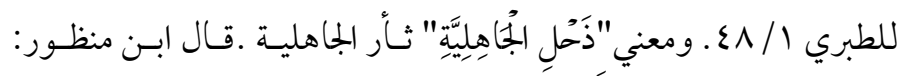

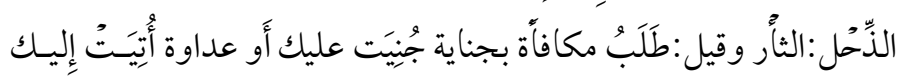

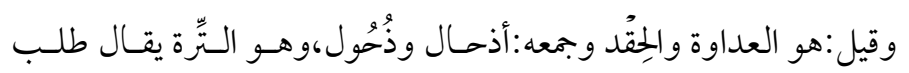

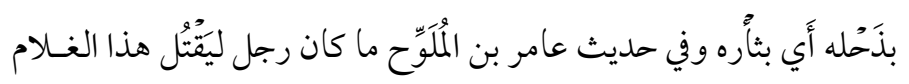

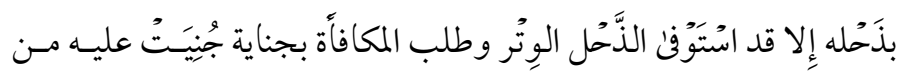

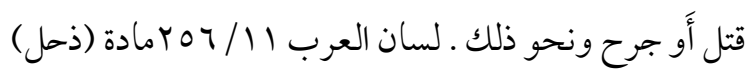

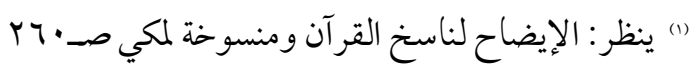




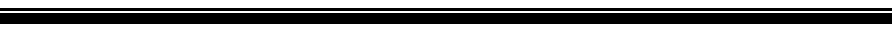

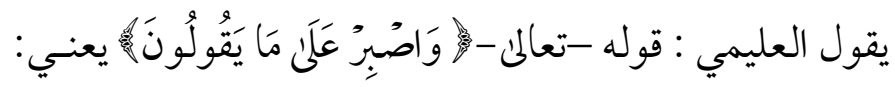

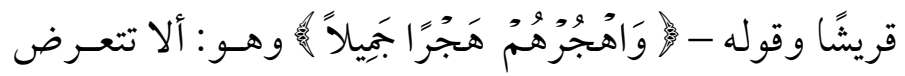

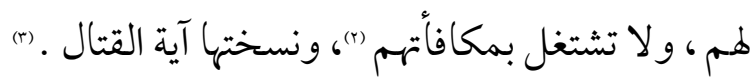

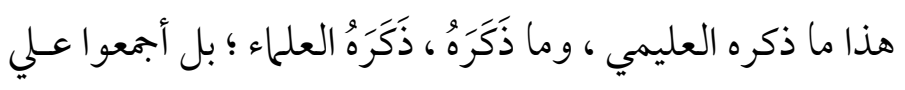

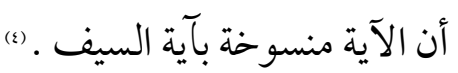

$$
\begin{aligned}
& \text { (1) سورة المزمل 1V • 1 1 }
\end{aligned}
$$

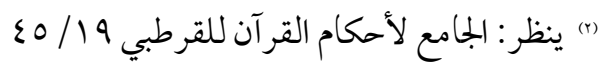

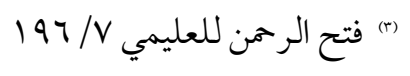

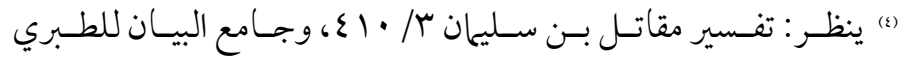

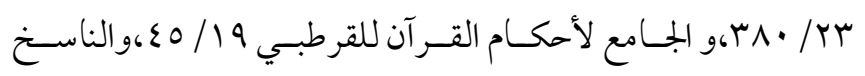

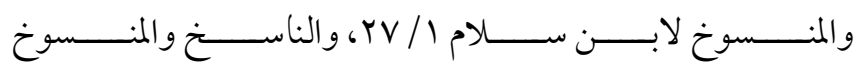

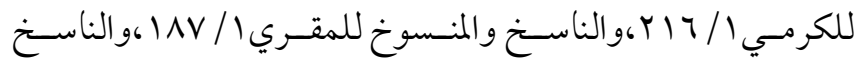

$$
\begin{aligned}
& \text { والمنسوخ للنحاس / Voo Vo ونواسخ القرآن لابن الجوزي إلا أنه يري } \\
& \text { أنها عكمة r/ عr. }
\end{aligned}
$$




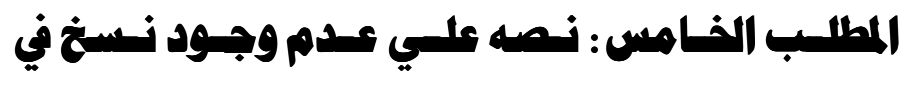

$$
\begin{aligned}
& \text { السورة.وهمو قاليل . }
\end{aligned}
$$

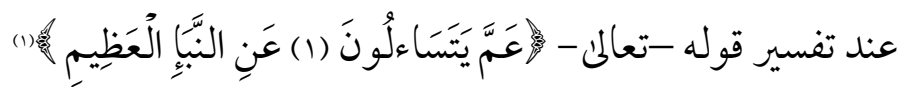

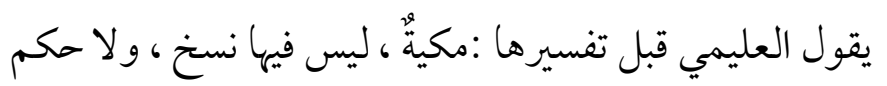

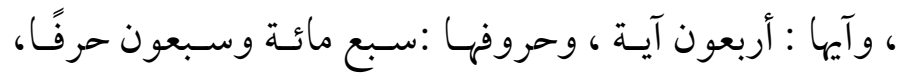

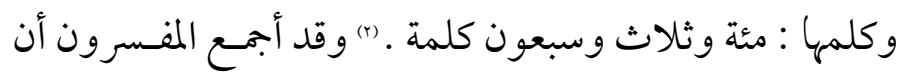

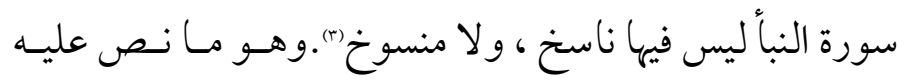

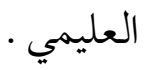

$$
\begin{aligned}
& \text { وورد في كتاب الناسخ والمنسوخ لابن حزم : سورة النبـأ مكيـة } \\
& \text { وجميعها عحكم. } \\
& \text { وقال عنها أيضاً ابن سلامة في كتابه الناسـخ والمنسوخ : سـورة } \\
& \text { النباً : نزلت بمكة وهي آخر المكي الأول ، لأن النبي - } \\
& \text { r-1/V) سورة النبأب(1) }
\end{aligned}
$$

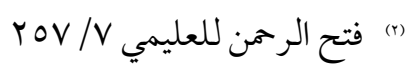

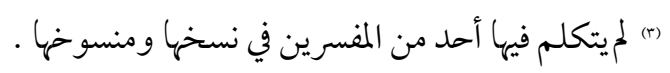

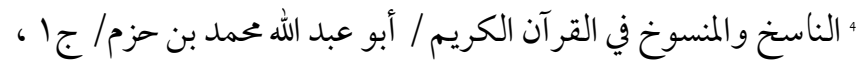

$$
\begin{aligned}
& \text { صعا _تتقيق عبد الغفار سليان البنداري-دار الكتب العلمية بيروت- }
\end{aligned}
$$

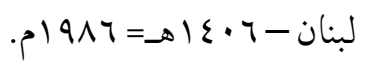




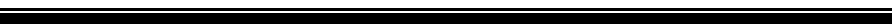

ثاني يوم نزلت. و المكي الأول ما نزل قبل الهجرة والمكي الآخر ما نزل بعد فتح مكة وهي محكمة، ليس فيها ناسخ ولا منسوخ.

$$
\begin{aligned}
& \text { ا الناسخ والمنسوخ / المؤلف أبو القاسم هبة الله بن سلامة بن نصر بن علي }
\end{aligned}
$$

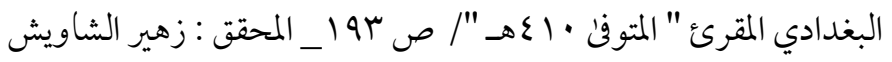

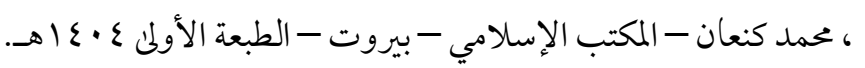




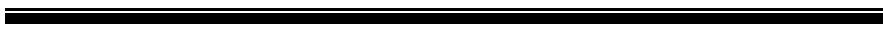

$$
\begin{aligned}
& \text { الخـــــاتــــة } \\
& \text { الحمد لله رب العالمين، والـصلاة والـسلام عسلي أشرف } \\
& \text { المرسلين، سيدنا محمد وعلئ آله وأصحابه أجمعين } \\
& \text { وبعــــ66،6، } \\
& \text { فهذه أهم النتائج التي توصلت إليها من خلال البحث : } \\
& \text { 1 - كثرة وتنوع مؤلفات "العليمي " في الدراسـات القرآنيـة }
\end{aligned}
$$

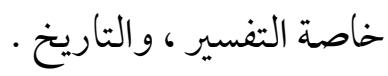

$$
\begin{aligned}
& \text { r- أن "العليمي" قد اتخذ لنفسه منهجا، و اختط خطـة التـزم } \\
& \text { بها، وسار عليها، ونص علئ ذلك في مقدمة تفسيره. } \\
& \text { ع اعتهاد "العليمي " علنم تفـسير "معـالم التنزيـل " للبغــوي }
\end{aligned}
$$

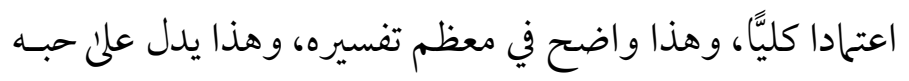

$$
\begin{aligned}
& \text { هذا التفسير. } \\
& \text { 0 - اهتحام العليمي بذكر الناسخ والمنسوخ في تفسيره . } \\
& 7 \text { - عرضه للأقو ال في الآية الناسخة و المنسوخ · } \\
& \text { V - إكثاره من ذكر المنسوخ بآية السيف أو القتال. }
\end{aligned}
$$


=

$-7 \wedge$ - 